\title{
Substitution between Cars within the Household
}

de Borger, Bruno ; Mulalic, Ismir; Rouwendal, Jan

Publication date:

2013

Document Version

Publisher's PDF, also known as Version of record

Link back to DTU Orbit

Citation (APA):

de Borger, B., Mulalic, I., \& Rouwendal, J. (2013). Substitution between Cars within the Household. University of Antwerp. http://econpapers.repec.org/paper/dgruvatin/20130158.htm

\section{General rights}

Copyright and moral rights for the publications made accessible in the public portal are retained by the authors and/or other copyright owners and it is a condition of accessing publications that users recognise and abide by the legal requirements associated with these rights.

- Users may download and print one copy of any publication from the public portal for the purpose of private study or research.

- You may not further distribute the material or use it for any profit-making activity or commercial gain

- You may freely distribute the URL identifying the publication in the public portal

If you believe that this document breaches copyright please contact us providing details, and we will remove access to the work immediately and investigate your claim. 


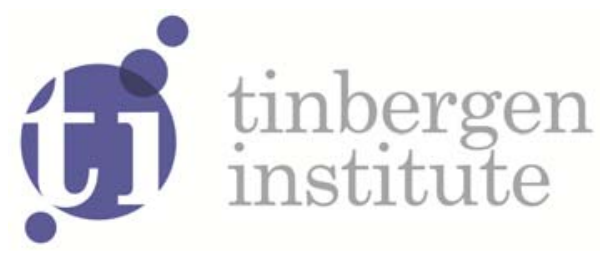

\title{
Substitution between Cars within the Household
}

\author{
Bruno De Borger \\ Ismir Mulalic ${ }^{2}$ \\ Jan Rouwenda/3
}

1 University of Antwerp, Belgium;

2 Technical University of Denmark, Denmark;

3 Faculty of Economics and Business Administration, VU University Amsterdam, and Tinbergen Institute. 
Tinbergen Institute is the graduate school and research institute in economics of Erasmus University Rotterdam, the University of Amsterdam and VU University Amsterdam.

More TI discussion papers can be downloaded at http://www.tinbergen.nl

Tinbergen Institute has two locations:

Tinbergen Institute Amsterdam

Gustav Mahlerplein 117

1082 MS Amsterdam

The Netherlands

Tel.: +31(0)205251600

Tinbergen Institute Rotterdam

Burg. Oudlaan 50

3062 PA Rotterdam

The Netherlands

Tel.: +31(0)10 4088900

Fax: $+31(0) 104089031$

Duisenberg school of finance is a collaboration of the Dutch financial sector and universities, with the ambition to support innovative research and offer top quality academic education in core areas of finance.

DSF research papers can be downloaded at: http://www.dsf.nl/

Duisenberg school of finance

Gustav Mahlerplein 117

1082 MS Amsterdam

The Netherlands

Tel.: +31(0)20 5258579 


\title{
Substitution between cars within the household
}

\author{
Bruno De Borger \\ Department of Economics, University of Antwerp, Belgium \\ bruno.deborger@ua.ac.be \\ Ismir Mulalic \\ Department of Transport, Technical University of Denmark, Denmark \\ imu@transport.dtu.dk \\ Jan Rouwendal \\ Department of Spatial Economics, VU University, Amsterdam \\ j.rouwendal@,vu.nl
}

\begin{abstract}
In this paper we study the demand for car kilometres in two-car households, focusing on the substitution between cars in response to fuel price changes. We use a large sample of detailed Danish data on two-car households to estimate -- for each car owned by the household -- own and cross-price effects of increases in fuel costs per kilometre. The empirical results show that failure to capture substitution between cars within the household can result in substantial misspecification biases. Ignoring substitution, we estimate fuel price elasticities of -0.81 and -0.65 for the primary and secondary cars, respectively. When we do take into account the substitution effect, these figures reduce to, respectively, -0.32 and -0.45 . We further estimate an alternative version of the model to test the hypothesis that substitution in response to higher fuel prices will be predominantly from the least to the most fuel efficient car, finding partial support for the underlying hypothesis. More importantly, the results of this extended model emphasize the importance of behavioural differences related to the position of the most fuel efficient car in the household, suggesting that households' fuel efficiency choices are related to their price sensitivity.
\end{abstract}

Keywords: Fuel efficiency, car use, multiple car ownership, substitution effects, fuel consumption.

JEL codes: D12, R41, Q41.

Acknowledgements The authors thank to Statistics Denmark and the Danish car dealer association (Danmarks Automobilforhandler Forening) for providing the data. Research support from the Danish Council for Strategic Research is acknowledged. 


\section{Introduction}

Increasing environmental awareness in transport policy-making, concerns of energy security and increasing fuel prices have generated a recent revival of interest in the economic implications of fuel prices on car use (see, among many others, West (2004), Gillingham (2012), and Linn (2013)). The purpose of this paper is to contribute to this literature by studying how two-car households react to changes in fuel prices that affect the relative per-kilometre cost of using the different cars. Based on a simple theoretical framework, we develop an econometric model that allows us to investigate whether, and to what extent, there is substitution between cars within the household. To analyze such effects, we use a large sample of two-car households for Denmark and estimate own and cross-price effects of increases in fuel prices. The empirical results point at important substitution effects, so that models that estimate responses to fuel prices on the implicit or explicit assumption of one car per household imply substantial biases. Moreover, substitution within the household may be an important component of the rebound effect: exogenous improvements in fuel efficiency reduce the per-kilometer cost of driving, raising the demand for kilometres and, hence, reducing any fuel savings better fuel efficiency imply. Although the rebound effect holds for onecar households, substitution between cars within the household strengthens this effect to the extent that there is substitution towards a relatively higher use of the most fuel efficient car (see, for example, Linn (2013)).

Of course, there is a large theoretical and empirical discrete choice literature dealing with households' choice of the number and type of cars to own, and the associated demand for car kilometers. Among many others, Mannering and Winston (1985), Train (1986) and De Jong (1990, 1991) developed detailed empirical analyses of car ownership and car use in both single and multiple vehicle households. Fullerton and Gan (2005) and Feng et al. (2005) analyze empirical models that allow simultaneous estimation of decisions related to car ownership, car type and 
kilometre demand, and they use the models to study the relative efficiency of different emission reduction policies (emission tax, fuel tax, annual registration fees, etc.). However, all these models typically either ignore substitution effects between cars in multiple car households, or deal with such possibilities in an ad hoc way. ${ }^{1}$ This is somewhat surprising because, in an early study, Mannering (1983) did allow for substitution possibilities in an econometric analysis of car use in households with multiple vehicles, and indeed found significant substitution effects between cars. Similarly, Golob and McNally (1997) and Golob et al. (1996) have emphasized travel interactions within households.

Our paper also relates to the extensive recent literature that specifically focuses on the economic effects of changes in gasoline prices. First, some studies have focused on the implications for the car market itself. For example, Busse et al. (2009) study the equilibrium market adjustments in response to changes in fuel prices and other usage cost. They find that in the new car market, the adjustment is primarily in market shares, while in the used car market the adjustment is primarily in prices. Klier and Linn (2010) find that higher gas prices drive up prices of highly fuel efficient vehicles. Demand responses are significant; the authors argue that nearly half of the decline in market share of U.S. manufacturers from 2002-2007 was due to the increase in the price of gasoline. Increases in the gasoline tax were found to have remarkably modest effects on average fuel economy of new cars. In line with intuition, changes in market share of cars of high fuel efficiency, due to increased production of such vehicles and scrappage of low fuel economy vehicles, attenuate price changes (Li et al. (2009) and Allcott and Wozny (2010)). Second, a few recent studies have focused on the implications of fuel price changes for the demand for car use. Gillingham (2012) correctly argues that household choices of vehicle and utilization of the vehicle are closely linked: vehicle choice is affected by how much consumers anticipate using it, and the

\footnotetext{
${ }^{1}$ A small literature focusing on issues of optimal taxation of different types of cars (e.g., diesel versus gasoline) has also limited the analysis to single car owners (see, e.g., Chia et al. (2001), De Borger and Mayeres (2007)).
} 
characteristics of the good such as fuel efficiency in turn influences subsequent usage. He estimates an empirical model based on these premises and explores the implications of ignoring the "selection on anticipated usage". Using a dataset of new personal vehicle registrations and odometer readings in California, he estimates a medium-run gasoline price elasticity of driving of -0.15 and of fuel economy of 0.09 . He emphasizes that ignoring the selection issue leads to an over-estimate of the gasoline price responsiveness. Simulation of a gasoline tax and feebate suggests a relatively small short-run rebound effect of increased driving. Most recently, Linn (2013) relaxes three implicit assumptions in earlier econometric models of demand for driving and fuel use: (i) that fuel economy is uncorrelated with other vehicle attributes, (ii) that fuel economy is uncorrelated with attributes of other vehicles owned by the household, and (iii) that the effect of gasoline prices on vehicle miles traveled is inversely proportional to the effect of fuel economy. He finds a large and robust rebound effect: a one percent fuel economy increase raises driving by 0.2 to 0.4 percent.

Finally, although our model will not incorporate distributional considerations, note that a small but growing literature has emphasized that the distributive effects of changes in gasoline prices can be large. Early studies include, for example, Hausman and Newey (1995), West (2004) and West and Williams (2005). More recent papers by Bento et al. (2009) and Jacobsen (2013) incorporate the supply side of the car market into the analysis, confirming that fuel prices and fuel efficiency standards have substantial distributional effects.

The paper is structured as follows. In Section 2, we describe the setup of a basic economic model that serves as background for the empirical analysis. Focusing on two-car households, the model explains household demands for kilometres driven by the different cars, conditional on owning two cars. The empirical model emphasizes one specific prediction, viz., households' demand for the use of cars with different fuel efficiencies in response to changes in fuel prices. Section 3 presents the specification of the empirical model, and it describes the data and the 
main characteristics of the sample selection process. Empirical results of the basic model are presented and discussed in Section 4, emphasizing the implications of the estimates for substitution of cars within the household. In section 5 we estimate an alternative model to test the idea that households substitute mainly from the least to the most fuel efficient car in response to an increase in the fuel price. This is suggested by common sense but, as the analysis shows, is not implied by the standard model of consumer behaviour. Section 6 reports some additional empirical work to check the robustness of the results. Conclusions are summarized in Section 7.

\section{Substitution between cars within the household: a simple theoretical framework}

It seems instructive to start by pointing out that a household's problem of deciding on car ownership and car use can be studied at three different levels. First, conditional on owning cars of given characteristics, in the very short-run, households can be thought of as choosing optimal quantities of the aggregate consumer good and the optimal demand for kilometres. Second, conditional on owning a given number of cars, the problem of the optimal characteristics (fuel efficiency) of the car together with optimal consumption of goods and kilometres could be studied. Third, the most general formulation would allow one to jointly analyze households' optimal choices with respect to the number and types of cars to own and the demand for kilometres and other goods. The focus of the empirical analysis in the next sections is on the first level, the short-run problem of the optimal use of a given number of cars with given characteristics.

In this section, we therefore develop a simple economic framework for the choice of car use by households, conditional on owning two cars. Assume that the household cares for a general numeraire consumption good $x$ and for kilometres travelled by the two cars owned. Denote the demand for kilometres by $q_{1}, q_{2}$ for the first and second cars, respectively. Car $i$ 's fuel efficiency (quality) is $E_{i}$; it gives the distance a car can travel per liter of fuel consumed. To 
facilitate the derivations below, it will be instructive to also define inverse fuel efficiency (fuel consumption per unit of distance); this is denoted by $g_{i}=1 / E_{i}$.

Since this paper focuses on the relative use of cars with different fuel efficiencies, we assume fuel is the only variable cost. The fuel cost per kilometre driven by car $i$ is then defined as

$$
P_{i}=P_{i}^{f} g_{i}
$$

where $P_{i}^{f}$ is the price per litre of the fuel used by car $i$. A wide range of fuel efficiencies is available on the market we study (new cars, second-hand markets). Since our model focuses on short-run reactions within households in the use of the different cars after a change in fuel prices, we ignore the long-run impact of fuel prices on annual ownership costs.

Specifically, the short-run problem of choosing optimal quantities of other goods and kilometres by the two cars owned, conditional on having two cars with given fuel efficiencies is to

$$
\max _{x, q_{1} q_{2}} u\left(q_{1}, q_{2}, x\right) \text { s.t. } x+P_{1}^{f} \bar{g}_{1} q_{1}+P_{2}^{f} \bar{g}_{2} q_{2}=y-f\left(\bar{g}_{1}\right)-f\left(\bar{g}_{2}\right)
$$

where we use bars to indicate that $\bar{g}_{1}, \bar{g}_{2}$ are given. We assume that at the optimum both $q_{1}>0$, $q_{2}>0$. The short-run optimization problem then implies demands:

$$
\begin{aligned}
& q_{1}\left(y-f\left(\bar{g}_{1}\right)-f\left(\bar{g}_{2}\right), P_{1}, P_{2}\right) \\
& q_{2}\left(y-f\left(\bar{g}_{1}\right)-f\left(\bar{g}_{2}\right), P_{1}, P_{2}\right)
\end{aligned}
$$

where $P_{1}=P_{1}^{f} \bar{g}_{1} ; P_{2}=P_{2}^{f} \bar{g}_{2}$.

The price effects implied by these equations are easiest to analyze if the two cars use different fuels, since then one price can move independently of the other. Differentiating (3), we have

$$
\begin{array}{ll}
\frac{\partial q_{1}}{\partial P_{1}^{f}}=\frac{\partial q_{1}}{\partial P_{1}} \bar{g}_{1} ; & \frac{\partial q_{2}}{\partial P_{1}^{f}}=\frac{\partial q_{2}}{\partial P_{1}} \bar{g}_{1} \\
\frac{\partial q_{1}}{\partial P_{2}^{f}}=\frac{\partial q_{1}}{\partial P_{2}} \bar{g}_{2} ; & \frac{\partial q_{2}}{\partial P_{2}^{f}}=\frac{\partial q_{2}}{\partial P_{2}} \bar{g}_{2}
\end{array}
$$


An increase in the price of the fuel used by car 1 has an impact on the number of kilometres driven by both car 1 and car 2 . A sufficient condition for the first effect to be negative is that kilometres driven by car 1 is a normal good. ${ }^{2}$ Intuitively, the second effect is caused by substitution: some of the kilometres formerly driven by car 1 are now realized by car 2, which has become relatively cheaper. ${ }^{3}$ We thus expect this substitution effect to be positive, even if the variable cost of car 2 is higher than that of car 1 . The effects of an increase in the price of the fuel used by car 2 are similar.

In many cases the two cars use the same fuel type. Then the percentage changes in the two prices are always identical, and Hicks' composite commodity theorem applies (see Deaton and Muellbauer, 1980, p. 120-122). The implication is that only the net price effect on the demand for kilometres of both cars jointly can be identified. Still, it is instructive to work out the implications of (3) in case the two cars use the same fuel. Differentiating demand system (3) and dropping the suffix of the fuel price (since fuel type is the same), we have

$$
\begin{aligned}
& \frac{\partial q_{1}}{\partial P^{f}}=\frac{\partial q_{1}}{\partial P_{1}} \bar{g}_{1}+\frac{\partial q_{1}}{\partial P_{2}} \bar{g}_{2} \\
& \frac{\partial q_{2}}{\partial P^{f}}=\frac{\partial q_{2}}{\partial P_{1}} \bar{g}_{1}+\frac{\partial q_{2}}{\partial P_{2}} \bar{g}_{2}
\end{aligned}
$$

These equations show that, for both cars, the total impact of a fuel price change consists of two effects, which are likely to have a different sign. Assuming car kilometres are normal, economic theory implies that the total number of kilometres driven by the household should decrease in response to an increase in the fuel price:

$$
\frac{\partial q_{1}}{\partial P^{f}}+\frac{\partial q_{2}}{\partial P^{f}}=\left(\frac{\partial q_{1}}{\partial P_{1}}+\frac{\partial q_{2}}{\partial P_{1}}\right) \bar{g}_{1}+\left(\frac{\partial q_{1}}{\partial P_{2}}+\frac{\partial q_{2}}{\partial P_{2}}\right) \bar{g}_{2}<0
$$

\footnotetext{
${ }^{2}$ Throughout this paper we - realistically - assume that demand for kilometers of both cars is normal.

${ }^{3}$ The formal definition of substitutes used in economics is based on the sign of the Slutsky terms. The substitution effect on the uncompensated (Marshallian) demand function that we discuss here is often referred to as gross substitutability. Good 1 and 2 are gross substitutes if the demand for good 1 increases when the price of good 2 increases, and the other way around. In this paper attention focuses on gross substitutability.
} 
This inequality can only hold for all possible values of $\bar{g}_{1}$ and $\bar{g}_{2}$ if both expressions in brackets are negative. This implies that the absolute value of the own price effect must be larger than the substitution effect. More importantly, although it implies that at least one of the derivatives $\frac{\partial q_{1}}{\partial P^{f}}$ and $\frac{\partial q_{2}}{\partial P^{f}}$ must be negative, it does not guarantee that both are negative: an increase in the fuel price may cause the number of kilometres driven by one of the cars to increase. That this possibility exists is obvious: as prices perfectly move together and one car is more fuel efficient than the other, the price increase may induce the household to use the most fuel efficient car more. Equations (4) suggest that this is more likely if there is a large difference between fuel uses per kilometre of the two cars.

The demand for kilometres and the quantity of fuel used are directly related via fuel efficiency. Letting $b$ denote total car fuel use by the household, we have:

$$
b=g_{1} q_{1}+g_{2} q_{2}
$$

Still assuming the two cars use the same fuel type, straightforward algebra shows that:

$$
\begin{aligned}
\frac{\partial b}{\partial P^{f}}=\left(\frac{\partial q_{1}}{\partial P_{1}}+\frac{\partial q_{2}}{\partial P_{1}}\right) & \left(\bar{g}_{1}\right)^{2}+\left(\frac{\partial q_{1}}{\partial P_{2}}+\frac{\partial q_{2}}{\partial P_{2}}\right)\left(\bar{g}_{2}\right)^{2}+ \\
& \frac{\partial q_{1}}{\partial P_{2}} \bar{g}_{2}\left(\bar{g}_{1}-\bar{g}_{2}\right)+\frac{\partial q_{2}}{\partial P_{1}} \bar{g}_{1}\left(\bar{g}_{2}-\bar{g}_{1}\right)
\end{aligned}
$$

Inequality (5) implies that the sum of the first two terms on the right-hand side of this expression will be negative. If the cross price effects are equal, as will be the case if there are no income effects, it is easily shown that the sum of the last two terms is also necessarily negative. ${ }^{4}$ This is a sufficient condition for the expected result that fuel use is a decreasing function of its price. Since one of the final two expressions is positive, the theory does not in general imply the intuitive idea that the possibility to switch between the two cars strengthens the sensitivity of the demand for fuel to changes in the fuel price.

\footnotetext{
${ }^{4}$ Because of Slutsky-symmetry.
} 
Expression (3) is the theoretical basis for the empirical model that will be estimated in the next sections, using detailed individual data for Denmark. The specification of the empirical model and the data used for the analysis imply that we will be able to observe fuel price variability even if the two cars are of the same fuel type, as explained in the next sections.

\section{The empirical model: specification and data}

In this section, we present the empirical model to study substitution between cars in two-car households in response to changes in fuel prices. We first describe the specification of the model and the identification strategy, next we present the data and discuss the sample selection.

\subsection{Model specification}

To guarantee the validity of the condition that $\bar{g}_{1}$ and $\bar{g}_{2}$ do not change, the focus in the empirical work is on all two-cars-households that do not change their car-stock in the period of observation (the econometric consequences of this restriction are discussed later in this section). We estimate the two demand equations (3) using Danish register data on all two-cars-households; car owners are matched to the car information available; this includes car attributes and odometer readings. Focusing on households that changed neither the number of cars in the household nor the type of each separate car within the period of observation implies that monthly vehicle usage (measured in kilometres) could be determined from actual odometer readings.

In the long-run the fuel cost per kilometre, defined as the ratio of fuel price and fuel

efficiency $\left(P=P^{f} g=P^{f} / E\right)$ is self-selected by the household through the choices of cars with a particular fuel efficiency. However, given car ownership in the short-run, changes in the fuel cost per kilometre are due only to fuel price fluctuations. The change in fuel price is induced by the fluctuations in the global fuel market and therefore exogenous with respect to decisions about the 
number of kilometres driven by each car in the household. The impact of changes in the fuel price on fuel cost per kilometre also depends on fuel efficiency as well as on the specific type of fuel used (for example, gasoline versus diesel).

Formally, our approach entails estimating the two household demand equations in first-differences to control for household-specific time-invariant factors. Let $q_{h, i, t}$ denote the natural logarithm of household $h$ 's demand for kilometre in year $t$ for car $i=1,2$. For the households in our sample, demand for kilometres is observed in different periods between odometer readings (see below for details), and we concentrate on changes between periods; this allows us to control for individual (fixed) effects. Specifically, the dependent variables are the changes in the natural logs of kilometres driven with the two cars. The own fuel costs per kilometre and the fuel cost per kilometre of the other car in the household are the crucial explanatory variables of interest. ${ }^{5} \mathrm{We}$ assume the following specification of household's demand for kilometres by car $i$ :

$$
\begin{aligned}
& \Delta q_{h, 1}=\beta_{1} \Delta P_{h, 1}+\gamma_{1} \Delta P_{h, 2}+\delta_{1} \Delta I_{h}+\theta_{1} \Delta X_{h, 1}+v_{h, 1} \\
& \Delta q_{h, 2}=\gamma_{2} \Delta P_{h, 1}+\beta_{2} \Delta P_{h, 2}+\delta_{2} \Delta I_{h}+\theta_{2} \Delta X_{h, 2}+v_{h, 2}
\end{aligned}
$$

where $\Delta$ denotes the time-difference operator and $v_{h, i}=u_{h, i, t}-u_{h, i, t-1} \cdot{ }^{6}$ Here, the $t$ refers to the different periods of observation. Thus, we use within-households' variation in fuel cost per kilometre to explain within-household's variation in demand for kilometres and further control for year-specific changes in household characteristics and income. Consistent estimation of $\beta$ and $\gamma$ requires that the changes in fuel cost per kilometre are exogenous and therefore not related to $v_{h, i}$. Since the choices of ownership level and vehicle type are predetermined, the changes in fuel costs per kilometre are due only to changes in fuel prices.

\footnotetext{
${ }^{5}$ Notice here that the extent to which cars can be used as substitutes may be constrained by potential incompatibilities between vehicle attributes and activity choices, by temporal conflicts, and by notions of vehicle ownership within the household (Mannering, 1983).

${ }^{6}$ Notice here that $\mathrm{u}_{\mathrm{h}, \mathrm{i}, \mathrm{t}}$ is the overall error.
} 
Estimating the model raises a number of concerns. First, some households may have switched to another car because of the change in fuel price. Hence our use of a sample of households who do not change their car-stock in the period of observation may suffer from selection bias. Below, we will explicitly address this issue by estimating Heckman selection models (Heckman (1978)). ${ }^{7}$ Second, another issue is the distinction between car 1 and car 2. Below we distinguish vehicles based on car usage, i.e., the primary car (car 1) is defined as the car being used most in the first period of observation. One may, however, argue that this distinction is somewhat arbitrary and not necessarily the most relevant one if one wants to study substitution behaviour. It is difficult to find better criteria for making the distinction. ${ }^{8}$ As noticed in the literature, this may be one reason for assuming that the parameters of the two-vehicle usage equations are symmetric (see Mannering, 1983). Finally, the system (6) represents two demand functions for the same household. This may cause correlation across the error terms $\left(\operatorname{corr}\left(v_{h, 1}, v_{h, 2}\right)\right)$ which can be used to improve efficiency in estimation by a seemingly unrelated regression (SUR) model (Zellner (1962)). ${ }^{9}$

\subsection{The data}

The data used in the empirical analysis are derived from two sources, viz., the annual register data from Statistics Denmark, and a car model database from the Danish car dealer association (DAF) for the years 2004-2008. In the car model database, we have information on car attributes of all model variants supplied on the car market in Denmark including, e.g., car brand/model/type and engine horsepower. Other information on car attributes and household characteristics is derived from annual register data from Statistics Denmark; variables include car tare and vintage, and

\footnotetext{
${ }^{7}$ Should usage be considered for all households, including those who change car-stock in the period of observation, car choice must be modelled jointly with vehicle usage using discrete/continuous econometric techniques (see Dubin and McFadden (1984); Train (1986); West (2004); and Bhat and Sen (2006)).

${ }^{8} \mathrm{We}$ will return to this issue in section 6.

${ }^{9}$ System (6) is derived from the simple economic theory presented in the previous section, so it seems natural to assume that $E\left(v_{h, i} \mid P_{1}^{v}, P_{2}^{v}, I_{i}, X_{i}\right)=0$ for $i=1,2$. For more detailed discussion on the SUR models, see Wooldridge (2010, chapter 7).
} 
information on household's socio-economic characteristics (e.g. income, presence of children, gender, age, etc.). We also have information on the car's owner. Although information on the car's principal driver would be more appropriate for our purposes, this information is not available. However, the assumption that a car is used mostly by the particular household member that is also the car's owner seems reasonable as a starting point. However, we will return to this issue later in the paper.

The number of kilometres driven has been calculated for each car in the sample using information on exact odometer readings from the so-called MOT-tests instituted by the Ministry of Transport. These are compulsory tests that take place every two years, starting after a new car has been in use for four years. We use three odometer readings for each car in the sample. The exact dates when the car passed its MOT-tests were registered, which provides us with fairly accurate information about the number of kilometres driven during the time interval between two subsequent MOT-tests. ${ }^{10}$ From three odometer readings, we are able to recover -- for each car in the sample -the average monthly number of kilometres driven in two periods: the first one starts in 2004 and ends in 2006 (or 2008 for new cars), the second runs from 2008 to $2010 .{ }^{11}$ However, note that we do not necessarily observe the kilometres driven by the two cars in a given household during (exactly) the same number of months, as the precise timing of the MOT-tests differs between households and cars (see footnote 10 above).

\footnotetext{
${ }^{10}$ The odometer readings are collected e.g. in months $\mathrm{m}_{0}$ and $\mathrm{m}_{1}$. This reveals the total number of kilometers driven between the two odometer readings $\left(\mathrm{m}_{0}\right.$ and $\left.\mathrm{m}_{1}\right)$. We can add up the demands for all months between $\mathrm{m}_{0}$ and $\mathrm{m}_{1}$ to derive an equation for total demand $\sum_{m=m_{0}}^{m=m_{1}-1} q_{1, m}=\left(m_{1}-m_{0}\right) \alpha_{1}+\beta_{1} \sum_{m=m_{0}}^{m=m_{1}-1} p_{1 m}+\gamma_{1} \sum_{m=m_{0}}^{m=m_{1}-1} p_{2 m}$. To account for the different length of the time intervals we divide by the length of the period between two odometer readings $\left(\mathrm{m}_{1}-\mathrm{m}_{0}\right)$ $\sum_{m=m_{0}}^{m=m_{1}-1} q_{1 m} /\left(m_{1}-m_{0}\right)=\alpha_{1}+\beta_{1} \sum_{m=m_{0}}^{m=m_{1}-1} p_{1 m} /\left(m_{1}-m_{0}\right)+\gamma_{1} \sum_{m=m_{0}}^{m=m_{1}-1} p_{2 m} /\left(m_{1}-m_{0}\right)$.

${ }^{11}$ Notice here that we use MOT test data for the period 2003-2011.
} 
The fuel cost per kilometre has been compiled as a ratio of the fuel price and the car's fuel efficiency. Fuel prices are taken from The Danish Petroleum Association web page (http://oliebranchen.dk/da-DK/Service/English.aspx); they are also averaged over the interval between MOT's. The car's fuel efficiency is derived from annual register data from Statistics Denmark. The specific (brand/model/make) car's fuel efficiency is based on the New European Driving Cycle (NEDC), this is a driving cycle designed to assess the emission levels of car engines and fuel economy in passenger cars (excluding light trucks and commercial vehicles). ${ }^{12}$ The units of all monetary amounts are (in real terms) DKK (1 DKK is approximately $0.13 €$.).

\subsection{Selection of sample and descriptive statistics}

We observe the full population of households in Denmark. Of these, 55.29\% own at least one car, and $8.15 \%$ own 2 cars $(222,309$ households). Records with missing information, households who changed their car stock between 2004 and 2008 (17,151), and households with company-cars (814) were excluded. This left us with a sample of 22,801 households and 45,602 cars.

Table 1 shows summary statistics of the variables of interest. They show that the primary car is on average newer, it is heavier and has a more powerful engine; overall, it consumes more fuel per kilometre. ${ }^{13}$ Moreover, the primary car is more likely to be a car with a diesel engine and, compared to the secondary car, it is more intensively used for commuting. The statistics also show that the average age and education levels of the owners of primary and secondary cars do not differ significantly. However, the primary car is more often owned by males compared to the secondary car. The fuel cost per kilometre increases for both cars between 2004 and 2008 .

\footnotetext{
${ }^{12}$ The database includes more than thousand car brand/model/make combinations. For a detailed documentation of the NEDC see Directive 98/69/EC of the European parliament and of the council of 13 October 1998 (http://eurlex.europa.eu/LexUriServ/LexUriServ.do?uri=CONSLEG:1998L0069:19981228:EN:PDF).

${ }^{13}$ Notice here that the focus is on the average car attributes including fuel efficiency. The histogram and kernel distribution for the difference of the fuel efficiency of the primary and the secondary car in a household are provided in Appendix A. They show that, in our sample, the secondary car consumes less fuel per kilometre in $61.10 \%$ cases (13,931 households).
} 
Although, on average, the change in the fuel cost per kilometre is very low, the high standard deviation indicates that we have, at least potentially, sufficient variation in exogenous fuel cost changes. Figure 1 shows the real fuel prices for the years 2004-2008. The change in number of driven kilometres moved, on average -- as one may expect given the attributes of the household's cars -- in opposite direction, -0.24 and 0.05 for the primary car and secondary cars, respectively. Household income increased by approx. 124 thousand DKK between 2004 and 2008.

Table 1. Summary statistics

\begin{tabular}{|c|c|c|c|c|}
\hline Variable & Mean & Std. Dev. & Minimum & Maximum \\
\hline Number of driven kilometres, car 1 (1000 km/month) & 1.7492 & 0.828 & 0.1458 & 9.3043 \\
\hline Fuel price, car 1 (DKK/I) & 8.4063 & 0.3702 & 6.8317 & 9.377 \\
\hline Fuel efficiency, car 1 (km/l) & 13.9838 & 3.4103 & 6.0000 & 33.3000 \\
\hline Car total weight, car $1(\mathrm{~kg})$ & $1,704.9950$ & 296.1480 & 975.0000 & $24,000.0000$ \\
\hline Engine horsepower, car 1 & 117.4046 & 33.7657 & 41.0000 & 408.0000 \\
\hline Car age, car 1 (years) & 6.0258 & 3.6159 & 0.0000 & 40.0000 \\
\hline Diesel engine (share), car 1 & 0.1669 & 0.3729 & 0.0000 & 1.0000 \\
\hline Car 1 owners age & 49.5477 & 11.5719 & 17.0000 & 91.0000 \\
\hline Male (share), car 1 & 0.7473 & 0.4345 & 0.0000 & 1.0000 \\
\hline Vocational education, owner of car 1 & 0.3607 & 0.4802 & 0.0000 & 1.0000 \\
\hline Short-cycle higher, owner of car 1 & 0.0660 & 0.2482 & 0.0000 & 1.0000 \\
\hline Medium-cycle education, owner of car 1 & 0.1945 & 0.3958 & 0.0000 & 1.0000 \\
\hline Bachelor, owner of car 1 & 0.0090 & 0.0944 & 0.0000 & 1.0000 \\
\hline Long-cycle higher education, owner of car 1 & 0.1529 & 0.3599 & 0.0000 & 1.0000 \\
\hline PhD degree, owner of car 1 & 0.0094 & 0.0966 & 0.0000 & 1.0000 \\
\hline Alien (share), owner of car 1 & 0.0177 & 0.1318 & 0.0000 & 1.0000 \\
\hline Car 1 owners commuting distance $(\mathrm{km})$ & 18.5995 & 28.8180 & 0.0000 & 371.9800 \\
\hline Number of driven kilometres, car 2 (1000 km/month) & 0.9001 & 0.4777 & 0.0139 & 4.8636 \\
\hline Fuel price ,car 2 (DKK/I) & 8.4344 & 0.2410 & 6.9434 & 9.2961 \\
\hline Fuel efficiency, car 2 (km/l) & 14.3997 & 2.2462 & 6.7000 & 33.3000 \\
\hline Car total weight, car $2(\mathrm{~kg})$ & $1,512.007$ & 258.3348 & 925.0000 & $15,550.0000$ \\
\hline Engine horsepower, car 2 & 98.1868 & 29.6926 & 26.0000 & 408.0000 \\
\hline Car age, car 2 (years) & 8.7949 & 5.1850 & 0.0000 & 44.0000 \\
\hline Diesel engine (share, car 2) & 0.0418 & 0.2001 & 0.0000 & 1.0000 \\
\hline Car 2 owners age & 49.2606 & 11.5848 & 17.0000 & 91.0000 \\
\hline Male, car 2 (share) & 0.6136 & 0.4869 & 0.0000 & 1.0000 \\
\hline Vocational education, owner of car 2 & 0.3693 & 0.4826 & 0.0000 & 1.0000 \\
\hline Short-cycle higher, owner of car 2 & 0.0660 & 0.2482 & 0.0000 & 1.0000 \\
\hline Medium-cycle education, owner of car 2 & 0.1957 & 0.3967 & 0.0000 & 1.0000 \\
\hline Bachelor, owner of car 2 & 0.0096 & 0.0978 & 0.0000 & 1.0000 \\
\hline Long-cycle higher education, owner of car 2 & 0.1343 & 0.3410 & 0.0000 & 1.0000 \\
\hline PhD degree, owner of car 2 & 0.0087 & 0.0930 & 0.0000 & 1.0000 \\
\hline Alien (share), owner of car 2 & 0.0177 & 0.1318 & 0.0000 & 1.0000 \\
\hline Car 2 owners commuting distance $(\mathrm{km})$ & 16.1826 & 26.9176 & 0.0000 & 371.9800 \\
\hline Household's income (1000 DKK) & 767.9359 & 329.3756 & 200.0530 & $2,984.1840$ \\
\hline Number of persons in household & 2.9070 & 1.0822 & 1.0000 & 10.0000 \\
\hline Baby (share) & 0.0434 & 0.2037 & 0.0000 & 1.0000 \\
\hline Children 1-6 years old (share) & 0.1828 & 0.3865 & 0.0000 & 1.0000 \\
\hline Children $7-18$ years old (share) & 0.3286 & 0.4697 & 0.0000 & 1.0000 \\
\hline Both cars owned by the same household member & 0.5376 & 0.4986 & 0.0000 & 1.0000 \\
\hline Share of households with both cars using different fuel types & 0.8324 & 0.3735 & 0.0000 & 1.0000 \\
\hline Change in number of driven kilometres, car 1 (1000 km/month) & -0.2371 & 0.7173 & -4.4983 & 4.3504 \\
\hline Change in number of driven kilometres, car $2(1000 \mathrm{~km} /$ month $)$ & 0.0479 & 0.5666 & -4.2984 & 4.4962 \\
\hline Change in fuel cost per kilometre, car 1 (DKK/ km) & 0.0021 & 0.0142 & -0.0669 & 0.0651 \\
\hline Change in fuel cost per kilometre, car $2(\mathrm{DKK} / \mathrm{km})$ & 0.0077 & 0.0075 & -0.0674 & 0.0601 \\
\hline Change in household's income (1000 DKK) & 124.0299 & 393.5885 & $-2,538.0570$ & $12,600.0000$ \\
\hline
\end{tabular}


Figure 1. Fuel prices for years 2004-2008 (real terms, 2000 DKK)

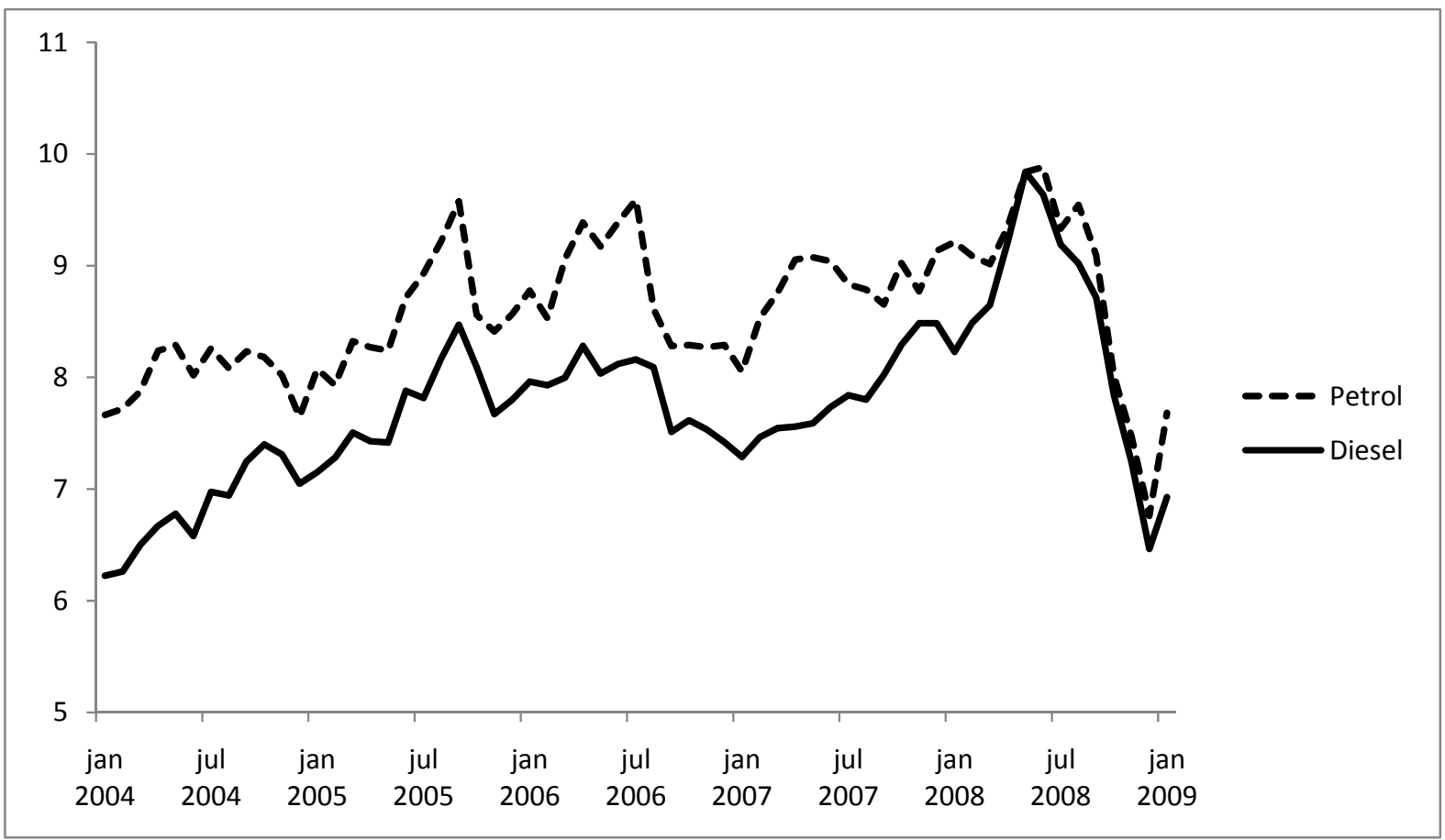

In Table 2 we present the correlation between changes in the number of kilometres driven and changes in the fuel price. The correlations reflecting own price responses are negative and the correlations reflecting cross price effects are positive, as expected. This is a first indication of possible substitution across vehicles within the considered two-car households.

Table 2. Correlation between changes in the fuel price per kilometre and changes in car use

\begin{tabular}{lll}
\hline & $\begin{array}{l}\text { Change in number of } \\
\text { driven kilometres, car 1 } \\
\text { (km/month) }\end{array}$ & $\begin{array}{l}\text { Change in number of } \\
\text { driven kilometres, car 2 } \\
\text { (km/month) }\end{array}$ \\
\hline Change in number of driven kilometres, car 2 (km/month) & 0.0541 & $\begin{array}{l}\text { Change in fuel } \\
\text { price, car 1 } \\
\text { (DKK/I) }\end{array}$ \\
Change in fuel price, car 1 (DKK/I) & -0.0332 & 0.0068 \\
Change in fuel price, car 2 (DKK/I) & 0.0005 & -0.0140 \\
\hline
\end{tabular}

Notes: Number of observations: 22,801 


\section{Empirical results}

The econometric results of first-difference models based on (6) are shown in Table 3. The first four columns show OLS results (model [1]) and SUR results (models [2]) for a log-linear specification of both demand and fuel cost changes.

The fuel costs per kilometre are statistically significant and have the expected signs, i.e. the own price effects are negative and the substitution effects are positive. These results confirm that households react to changes in fuel prices in a way consistent with economic theory. A Breusch-Pagan test rejects the hypothesis that the residuals from the two demand equations are independent $\left(\chi^{2}(1)=46.435\right) .{ }^{14}$ Moreover, although the seemingly uncorrelated regression (SUR) (a GLS estimator) method and OLS provide, in our case, the same set of coefficients, the SUR estimator is more efficient (see, for instance, Wooldridge, 2010, ch. 7). Consequently, we focus on the estimation results from [2].

The results are similar if we restrict the own price effects and the substitution effects to be symmetric (see [3] in Table 3). Moreover, the F test does not reject the hypothesis (at $1 \%$ significance level) that these effects are identical in [2]. ${ }^{15}$ Note that the symmetry does not imply that the effects of a fuel price increase are identical for the two cars: a given change in the fuel price implies a larger change in the cost per kilometre of the less fuel efficient car. Hence, two-carshouseholds will in response to a fuel price increase substitute more kilometres from the least to the most fuel-efficient vehicle than the other way around.

\footnotetext{
${ }^{14}$ An often used specification test for the SUR model is the Breusch-Pagan test of whether the residuals from the model equations are independent. The the Likelihood Ratio (LR) test statistic is given by $\mathrm{LR}=\mathrm{T} \sum_{\mathrm{m}=1}^{\mathrm{M}} \sum_{\mathrm{n}=1}^{\mathrm{N}} \mathrm{r}_{\mathrm{mn}}^{2}$, where $\mathrm{r}_{\mathrm{mn}}$ is the estimated correlation between the residuals of the $\mathrm{M}$ equations and $\mathrm{T}$ is the number of observations. It is distributed as $\chi^{2}$ with $\mathrm{M}(\mathrm{M}-1) / 2$ degrees of freedom. Chapter 26 of Ruud (2000) contains a discussion of the SUR model and the relevant specification test.

${ }^{15} H_{0}: \beta_{1}=\beta_{2}: \mathrm{F}=0.79$, p-value $=0.21, H_{0}: \gamma_{1}=\gamma_{2}: \mathrm{F}=0.33$, p-value $=0.42, H_{0}: \delta_{1}=\delta_{2}: F=0.29, p=0.45$.
} 
Table 3. First-difference demand models

\begin{tabular}{|c|c|c|c|c|c|c|c|c|}
\hline & \multicolumn{2}{|c|}{ [1] } & \multicolumn{2}{|c|}{ [2] } & \multicolumn{2}{|c|}{ [3] } & \multicolumn{2}{|c|}{ [4] } \\
\hline & \multicolumn{2}{|c|}{ OLS } & \multicolumn{2}{|c|}{ SUR } & \multicolumn{2}{|c|}{ SUR (symmetric) } & \multicolumn{2}{|c|}{ Heckman selection } \\
\hline & car 1 & car 2 & car 1 & car 2 & car 1 & car 2 & car 1 & car 2 \\
\hline \multirow[t]{2}{*}{ Change in fuel cost per kilometre, car 1 (DKK/km) } & $-1.630^{* * *}$ & $1.588^{* * *}$ & $-1.630^{* * *}$ & $1.588^{* * *}$ & $-1.766 * * *$ & $1.378^{* * *}$ & $-1.684^{* * *}$ & $1.621^{* * *}$ \\
\hline & $(0.213)$ & $(0.329)$ & $(0.236)$ & $(0.310)$ & $(0.209)$ & $(0.244)$ & $(0.172)$ & $(0.355)$ \\
\hline \multirow[t]{2}{*}{ Change in fuel cost per kilometre, car 2 (DKK/km) } & $1.142^{* *}$ & $-2.429 * * *$ & $1.142^{* *}$ & $-2.429 * * *$ & $1.378^{* * *}$ & $-1.766 * * *$ & $1.296 * *$ & $-2.727^{* * *}$ \\
\hline & $(0.469)$ & $(0.593)$ & $(0.445)$ & $(0.585)$ & $(0.244)$ & $(0.209)$ & $(0.513)$ & (0.629) \\
\hline \multirow[t]{2}{*}{ Change in log of household's income (1000 DKK) } & $0.027 * *$ & 0.014 & $0.027^{* *}$ & 0.014 & $0.022^{* * *}$ & $0.022 * * *$ & 0.011 & $0.081^{* *}$ \\
\hline & $(0.012)$ & $(0.014)$ & $(0.011)$ & $(0.014)$ & $(0.009)$ & $(0.009)$ & $(0.021)$ & $(0.033)$ \\
\hline \multirow[t]{2}{*}{ Change in number of persons in household } & $-0.014^{* *}$ & $-0.014^{*}$ & $-0.014^{* *}$ & $-0.014^{*}$ & $-0.014^{* *}$ & $-0.014^{*}$ & $-0.020 * *$ & 0.011 \\
\hline & $(0.006)$ & $(0.008)$ & $(0.006)$ & $(0.008)$ & $(0.006)$ & $(0.008)$ & $(0.009)$ & $(0.015)$ \\
\hline \multirow[t]{2}{*}{ Change in number of adults in household } & $0.017^{* *}$ & $0.030 * * *$ & $0.017^{* *}$ & $0.030 * * *$ & $0.017^{* *}$ & $0.029 * * *$ & $0.019 * *$ & 0.017 \\
\hline & $(0.007)$ & $(0.009)$ & $(0.007)$ & $(0.009)$ & $(0.007)$ & $(0.009)$ & $(0.008)$ & $(0.012)$ \\
\hline \multirow[t]{2}{*}{ Change of presence of children in household } & 0.014 & $0.028 * * *$ & $0.014^{*}$ & $0.028 * * *$ & $0.014^{*}$ & $0.028^{* *}$ & 0.013 & $0.029 * *$ \\
\hline & $(0.008)$ & $(0.010)$ & $(0.008)$ & $(0.011)$ & $(0.008)$ & $(0.011)$ & $(0.010)$ & $(0.013)$ \\
\hline \multirow[t]{2}{*}{ Change in commuting distance $(\mathrm{km})$} & $0.0004^{* * *}$ & $0.0005^{* * *}$ & $0.0004 * * *$ & $0.0005^{* * *}$ & $0.0004^{* * *}$ & $0.0005^{* * *}$ & $0.0003^{* * *}$ & $0.0007^{* * *}$ \\
\hline & $(0.0001)$ & $(0.0001)$ & $(0.0001)$ & $(0.0001)$ & $(0.0001)$ & $(0.0001)$ & $(0.0001)$ & $(0.0002)$ \\
\hline \multirow[t]{2}{*}{ Change in labour supply (1000 hours /year) } & $-2.16 e-06$ & $1.97 \mathrm{e}-07$ & $-2.15 e-06$ & $1.95 e-07$ & $-2.14 \mathrm{e}-06$ & $1.67 \mathrm{e}-07$ & $-1.93 e-06$ & $1.87 e-06$ \\
\hline & $(4.12 \mathrm{e}-06)$ & $(4.26 \mathrm{e}-06)$ & $(2.86 e-06)$ & $(3.77 e-06)$ & $(2.86 e-06)$ & $(3.77 e-06)$ & $(3.69 \mathrm{e}-06)$ & $(4.72 \mathrm{e}-06)$ \\
\hline \multirow[t]{2}{*}{ Mills ratio } & & & & & & & 0.194 & $-0.750^{* *}$ \\
\hline & & & & & & & $(0.171)$ & $(0.290)$ \\
\hline R-squared & 0.004 & 0.003 & 0.004 & 0.003 & 0.004 & 0.003 & & \\
\hline No. of observations & 22,801 & 22,801 & 22,801 & 22,801 & 22,801 & 22,801 & 39,031 & 39,037 \\
\hline
\end{tabular}

Notes: dependent variable is chg. in $\log (\mathrm{km} /$ month); for the first step of the Heckman selection model see Appendix B.***,**,* indicate that estimates are significantly different from zero at the 0.01 , at the 0.05 and the 0.10 level, respectively; robust standard errors are in parentheses. 
In order to address the potential bias related to our selection of households (so far we selected only those households that did not change the cars owned between the two periods), we have extended our data with two-cars-households that did change their car ownership in the period of observation. Summary statistics of the observed variables of interest for the less restrictive sample - provided in Appendix B - show that this descriptive information is fairly stable across different samples. In order to formally examine sample selection issues, we estimated Heckman selection models. The selection equation includes the age of the oldest car in the household as an additional variable. The age of the oldest car in the household has no direct effect on changes in the demand for kilometres, but it is most likely strongly correlated with the car replacement decision. The idea here is that some households (those with strong preferences for newer cars) replace their cars regularly (e.g. after 2-3 years).

In the last two columns in Table 3, we report the results of the Heckman selection model. The low standard error on the age of the oldest car in the household (as reported in Appendix C, see Table C.1) confirms that the instrument is strong. Note that the results obtained from the Heckman selection model are almost identical to those presented above. So, accounting for sample selectivity does not change our main result.

The results suggest that substitution is important; there is a substantial difference between the own price effect and the total impact that includes the substitution effect. To illustrate this, we consider the impact of an increase in the fuel price of 10 cents $(1.2 \%)$ for the 'average household,' that is a household owning cars with the average levels of fuel efficiency and driving the average number of kilometres. Specification [3] implies that for this artificial household the own price effect reduces driving with the first and second cars by 20.8 and $15.4 \mathrm{~km} / \mathrm{month}$, respectively. When the substitution effect is also taken into account, these figures reduce to 6.6 and 4.9 
$\mathrm{km} / \mathrm{month}$, which is roughly a quarter of the own price effect. This implies a net (including substitution effects) fuel price elasticity of -0.32 for car 1 and -0.45 for car 2 .

The large substitution effects that we find raise an interesting question. Suppose one estimates household's responses to fuel price changes, ignoring the issue of multiple cars per households and the potential substitution between cars at the household level, and that one uses the results to predict changes in the demand for car use. To what extent does this bias the predictions? To investigate the issue, we have estimated two equations -- referring to cars 1 and 2, respectively -that ignore the substitution effects; i.e., the price of using the other car in the household is not included. The results are given in columns [1] and [2] of Table 4. In both equations, the coefficient for the fuel cost per kilometre is notably lower in absolute terms than the own price effects reported in Table 3. For a proper comparison, we should of course compare the net effect of an increase in the price of fuel on the number of kilometres driven by either car. According to the equations estimated separately, the net effect of a 10 cent increase in the fuel price is now a decrease in the monthly number of kilometres of 17.0 for car 1 and 6.9 for car 2 . The associated price elasticities are -0.81 and -0.64 for car 1 and 2 , respectively. In both cases we thus find that ignoring substitution implies a sizeable overestimate of the impact of a fuel price increase.

We have also estimated a single equation that refers to the number of kilometres driven by all cars in the sample, treating the two cars as independent observations and again ignoring possible substitution effects. The surprising result, reported in column [3] of Table 4, is that the coefficient of the fuel cost per kilometre now has the wrong - positive - sign. Investigation of the background of this result showed that the impact of price changes on the number of kilometres is different for cars 1 and 2, as we document in Appendix D. ${ }^{16}$ We conclude that models

\footnotetext{
${ }^{16}$ This may appear to be surprising since we could not reject the symmetric model. Note, however, that the symmetry of the price effects does not exclude that other effects (for instance, of changes in household composition) are different for the two demand equations. Also note that the symmetric model was estimated by SUR taking into account possible dependencies between the error terms of the two demand equations.
} 
estimating responses to fuel price changes on the implicit or explicit assumption of one car per household may imply substantial biases in both directions.

Table 4. First-difference demand model that ignores the substitution effects

\begin{tabular}{|c|c|c|c|}
\hline & $\begin{array}{c}{[1]} \\
\text { only car } 1\end{array}$ & $\begin{array}{c}\text { [2] } \\
\text { only car } 2\end{array}$ & $\begin{array}{c}\text { [3] } \\
\text { both cars }\end{array}$ \\
\hline Change in fuel cost per kilometre (DKK/km) & $-1.363^{* * *}$ & $-1.107^{* *}$ & $0.479 * *$ \\
\hline & (0.198) & $(0.515)$ & $(0.187)$ \\
\hline Change in log of household's income (1000 DKK) & $\begin{array}{l}0.027^{* *} \\
(0.012)\end{array}$ & $\begin{array}{l}0.014 \\
(0.014)\end{array}$ & $\begin{array}{l}0.021^{* *} \\
(0.009)\end{array}$ \\
\hline Change in number of persons in household & $\begin{array}{l}-0.014^{* *} \\
(0.006)\end{array}$ & $\begin{array}{l}-0.014^{*} \\
(0.008)\end{array}$ & $\begin{array}{l}-0.014^{* * *} \\
(0.005)\end{array}$ \\
\hline Change in number of adults in household & $\begin{array}{l}0.017^{* *} \\
(0.007)\end{array}$ & $\begin{array}{l}0.030^{* * *} \\
(0.009)\end{array}$ & $\begin{array}{l}0.024 * * * \\
(0.006)\end{array}$ \\
\hline Change of presence of children in household & $\begin{array}{l}0.014^{*} \\
(0.008)\end{array}$ & $\begin{array}{l}0.027^{* * *} \\
(0.010)\end{array}$ & $\begin{array}{l}0.021 * * * \\
(0.007)\end{array}$ \\
\hline Change in commuting distance $(\mathrm{km})$ & $\begin{array}{l}0.0004^{* * *} \\
(0.0001)\end{array}$ & $\begin{array}{l}0.0005^{* * *} \\
(0.0001)\end{array}$ & $\begin{array}{l}0.0005^{* * *} \\
(0.0001)\end{array}$ \\
\hline Change in labour supply ( 1000 hours /year) & $\begin{array}{l}-2.17 e-06 \\
(4.12 e-06)\end{array}$ & $\begin{array}{l}1.25 \mathrm{e}-07 \\
(4.29 \mathrm{e}-06)\end{array}$ & $\begin{array}{l}-9.38 \mathrm{e}-07 \\
(3.00 \mathrm{e}-06)\end{array}$ \\
\hline $\begin{array}{l}\text { R-squared } \\
\text { No. of observations }\end{array}$ & $\begin{array}{l}0.004 \\
22.801\end{array}$ & $\begin{array}{l}0.002 \\
22.801\end{array}$ & $\begin{array}{l}0.002 \\
45.602\end{array}$ \\
\hline
\end{tabular}

To conclude this section note that, although substitution takes place in both directions, we expect the net effect to be substitution towards the most fuel efficient car. This suggest that the impact on fuel use is larger than that on the number of kilometres driven. To investigate this issue, we have computed the impact of 10 cent increase in the fuel price for both cars on the number of kilometres driven and on the amount of fuel used for the average household. Our computations are summarized in Table 5 below. The results confirm that the impact on total fuel use is larger than that on the total number of kilometres driven, but the implied elasticities are only marginally different. The reason is of course that the fuel efficiencies of cars 1 and 2 do on average differ little (see Table 1). For households that differ from the average household as defined here, the difference can be much larger. 
Table 5. The effect of an increase in the fuel price by 10 cents (1.2\%) on demand for kilometres for the average household

\begin{tabular}{|c|c|c|}
\hline & Primary car & Secondary car \\
\hline Change in demand for kilometres $\mathrm{km} / \mathrm{month}$ (own effect) & $\begin{array}{l}-20.85 \\
(10.10)\end{array}$ & $\begin{array}{l}-15.43 \\
(8.68)\end{array}$ \\
\hline Change in demand for kilometres $\mathrm{km} / \mathrm{month}$ (cross effect) & $\begin{array}{r}14.22 \\
(7.15) \\
\end{array}$ & $\begin{array}{c}10.57 \\
(5.77) \\
\end{array}$ \\
\hline $\begin{array}{l}\text { Change in demand for kilometres } \mathrm{km} / \mathrm{month} \text {, total effect } \\
\text { Change of the monthly demand for kilometres (pct.) }\end{array}$ & $\begin{array}{l}-6.63 \\
(5.63) \\
-0.38 \%\end{array}$ & $\begin{array}{l}-4.86 \\
(4.65) \\
-0.54 \%\end{array}$ \\
\hline Change of the monthly demand for kilometres for both cars ( $\mathrm{km} / \mathrm{month})$ & & \\
\hline Change of the monthly demand for kilometres (pct.) for both cars & & \\
\hline Change in monthly demand for fuel & & \\
\hline
\end{tabular}

Notes: all changes are calculated using estimated coefficients from table 3 ; standard errors are in parentheses.

\section{An alternative model}

The model estimated in the previous section is based on the standard model of consumer behaviour. The demands for kilometers by the two cars are treated in exactly the same way as the demands for two different consumer goods and no further constraints have been imposed. This implies that a fuel price increase will not only lead to substitution from the least to the most fuel efficient car, but substitution occurs also in the other direction. Although we have shown that the model implies -- at least in the symmetric case - that there will be more substitution from the least to the most fuel efficient car than in the reverse direction, it appears somewhat counterintuitive that substitution takes place in both directions.

In view of this discussion, we estimated an alternative demand model to test the simple idea that a change in the fuel price induces a household to switch trips from the least to the most fuel efficient car only. This alternative model distinguishes between the most and least fuel efficient car through a dummy variable that indicates that car 2 is the most fuel efficient one. If the alternative model is appropriate, there will only be substitution from car 1 to car 2 if the fuel price increases and car 2 is the most fuel efficient one. Similarly, there will only be substitution from car 2 to car 1 if the fuel price increases and car 1 is the most fuel efficient one. 
To test this hypothesis, we extend the model of the previous subsection with crossproducts of (i) a dummy variable indicating that car 2 is the most fuel efficient one and (ii) the change in the fuel costs of both cars. In the time interval we consider the general trend of fuel prices has been increasing. ${ }^{17}$ Our hypothesis would then be that, when the fuel price increases and car 1 is the most fuel efficient one, there should be no substitution from car 1 to car 2 . Similarly, one expects that substitution from car 2 to car 1 takes place if car 1 is the most fuel efficient one, whereas nothing should happen if car 2 is the most fuel efficient one. Finally, note that the same reasoning would lead one to expect a larger (in absolute value) own price effect when the car is the least fuel efficient one, since in that case the opportunity to switch to a more fuel efficient car is present.

The results of estimating the extended model are presented in Table 6 . We start by discussing the results for the demand equation of car 1 . The first coefficient indicates that the impact of a change in the own price per kilometer of car 1 on the demand for kilometres driven by this car is negative, as expected. According to the ideas underlying the alternative model, an increase in the price per kilometer of car 2 is expected to have a positive effect on the demand for the use of car 1, unless car 2 is the most fuel efficient one. The second line of the Table 6 confirms the first effect, and the fourth line shows that the substitution effect decreases substantially when car 2 is the most fuel efficient one. These results can thus be regarded as partial support for the alternative model. However, we note also from the third line of the Table that the own price effect for car 1 is smaller (in absolute value) if car 2 is the most fuel efficient one. This finding is less intuitive. A potential explanation is offered below.

For car 2 we also find a significantly negative own price effect. This effect is smaller (in absolute value) if car 2 is the most efficient, which is consistent with the idea suggested above.

\footnotetext{
${ }^{17}$ Figure 1 shows that there have also been price decreases in specific periods, especially at the end of the year 2008. However, the average price level in the period 2004-2006 is clearly lower than that in the period 2006-2008.
} 
An increase in the price per $\mathrm{km}$ of car 1 has a positive impact on the demand for kilometers of car 2 but, again contrary to the logic underlying the alternative model, this effect is smaller when car 2 is the most fuel efficient one.

Table 6. First-difference demand models with interactions terms

\begin{tabular}{|c|c|c|}
\hline & \multicolumn{2}{|c|}{ SUR } \\
\hline & car 1 & car 2 \\
\hline Change in fuel cost per kilometre, car 1 (DKK/ km) & $\begin{array}{l}-3.353 * * * \\
(0.439)\end{array}$ & $\begin{array}{l}3.102 * * * \\
(0.578)\end{array}$ \\
\hline Change in fuel cost per kilometre, car $2(\mathrm{DKK} / \mathrm{km})$ & $\begin{array}{l}2.811 * * * \\
(0.666)\end{array}$ & $\begin{array}{l}-3.959 * * * \\
(0.877)\end{array}$ \\
\hline $\begin{array}{l}\text { Change in fuel cost per kilometre, car } 1 \text { (DKK/ km) * dummy variable } \\
\text { indicating that car } 2 \text { is more fuel efficient }\end{array}$ & $\begin{array}{l}2.348 * * * \\
(0.520)\end{array}$ & $\begin{array}{l}-2.117 * * * \\
(0.685)\end{array}$ \\
\hline $\begin{array}{l}\text { Change in fuel cost per kilometre, car } 2(\mathrm{DKK} / \mathrm{km}) * \text { dummy variable } \\
\text { indicating that car } 2 \text { is more fuel efficient }\end{array}$ & $\begin{array}{l}-1.561 * \\
(0.912)\end{array}$ & $\begin{array}{l}2.209 * \\
(1.202)\end{array}$ \\
\hline Change in log of household's income ( 1000 DKK) & $\begin{array}{l}0.028 * * * \\
(0.011)\end{array}$ & $\begin{array}{l}0.014 \\
(0.014)\end{array}$ \\
\hline Dummy variable indicating that car 2 is more fuel efficient & $\begin{array}{l}0.069 * * * \\
(0.009)\end{array}$ & $\begin{array}{l}-0.021^{*} \\
(0.012)\end{array}$ \\
\hline Change in number of persons in household & $\begin{array}{l}-0.014^{* *} \\
(0.006)\end{array}$ & $\begin{array}{l}-0.014^{*} \\
(0.008)\end{array}$ \\
\hline Change in number of adults in household & $\begin{array}{l}0.016^{* *} \\
(0.007)\end{array}$ & $\begin{array}{l}0.031^{* * *} \\
(0.009)\end{array}$ \\
\hline Change of presence of children in household & $\begin{array}{l}0.012 \\
(0.008)\end{array}$ & $\begin{array}{l}0.028 * * * \\
(0.011)\end{array}$ \\
\hline Change in commuting distance $(\mathrm{km})$ & $\begin{array}{l}0.0004 * * * \\
(0.0001)\end{array}$ & $\begin{array}{l}0.0005^{* * *} \\
(0.0001)\end{array}$ \\
\hline Change in labour supply (1000 hours / year) & $\begin{array}{l}-2.07 \mathrm{e}-06 \\
(2.86 \mathrm{e}-06)\end{array}$ & $\begin{array}{l}1.49 \mathrm{e}-07 \\
(3.77 \mathrm{e}-06)\end{array}$ \\
\hline $\begin{array}{l}\text { R-squared } \\
\text { No. of observations }\end{array}$ & $\begin{array}{l}0.009 \\
22,801\end{array}$ & $\begin{array}{l}0.003 \\
22,801\end{array}$ \\
\hline
\end{tabular}

Clearly, our results do not provide a univocal endorsement of the alternative model that was primarily developed to investigate a specific asymmetry in behavioral responses. More in general, however, the model allows for differences in the response to fuel price changes between the least and the most fuel efficient cars. Seen from that point of view, it is interesting to observe that the extended model differs significantly from that of the previous section. ${ }^{18}$ The coefficients reported in the first two lines of Table 6 refer to the situation where car 1 is the most fuel efficient one. It is striking that all coefficients are larger in absolute values than those found in the models reported in Table 3. When car 2 is the most fuel efficient one, the net impact of the price change on the logs of the kilometers driven can be found by adding the relevant coefficients. The results are given in Table 7, where the reported standard errors have been computed by the delta method. Not

\footnotetext{
${ }^{18}$ A standard F-test $(\mathrm{F}=15.86$; $\mathrm{p}$-value $<0.0001)$ rejects the hypothesis that all the cross effects jointly are equal to zero.
} 
surprisingly, most of these coefficients are smaller in absolute value than those reported in Table $3 .^{19}$

Table 7. The fuel cost effect on the demand for kilometers when car 2 is the most fuel efficient

\begin{tabular}{lll}
\hline & chg. in $\log (\mathrm{km} / \mathrm{month})$, car1 & chg. in $\log (\mathrm{km} / \mathrm{month}), \mathrm{car} 2$ \\
\hline Change in fuel cost per kilometre, car 1 (DKK/ km) & $-1.005^{* * *}$ & $0.985^{* * *}$ \\
& $(0.279)$ & $(0.368)$ \\
Change in fuel cost per kilometre, car 2 (DKK/ $\mathrm{km})$ & $1.251^{* *}$ & $-1.750^{* *}$ \\
& $(0.624)$ & $(0.822)$ \\
\hline
\end{tabular}

Summarizing, the extended model estimated in this section did not fully support the asymmetric responses suggested above. However, it did bring to light that there are substantial behavioral differences related to the position of the most fuel efficient car in the household. Interestingly, means for samples distinguishing between the households in which the primary car is more fuel efficient and the households in which the secondary car is more fuel efficient show that these households significantly differ in demand for kilometers, see Table E1 in Appendix E. The households in which the primary car is more fuel efficient have higher demand for kilometers and higher demand for cars with diesel engine (these households own also more often two cars that use the different type of fuel, i.e. diesel). Moreover, commuting distance is significantly higher for these households while the household's income is to some extent lower. Clearly, as Mannering (1983) already argued, the substitution between cars is also affected by activity choices, by temporal conflicts, and by the nature of vehicle ownership within the household.

Note that the fact that fuel efficiencies are actually chosen by households, combined with the observed behavioral differences depending on the position of the most fuel efficient car in the household, may partially explain some of the counterintuitive results mentioned above. Indeed, our estimation results are consistent with the existence of a relation between households' choices of

\footnotetext{
${ }^{19}$ Figure E1 in Appendix E shows also that an increase in the fuel cost per kilometre by 10 cents implies a decrease in demand for kilometres for the primary car in $93.98 \%$ of cases, for the secondary car in $95.71 \%$ of cases, and in total in $99.77 \%$ of cases.
} 
fuel efficiency and their price sensitivity to fuel price increases. For example, suppose drivers who are inflexible with respect to the kilometers they drive (e.g., they have a long commute and no possibility to telework) choose a more luxury car that is less fuel efficient. This would potentially explain our findings related to car 1 in Table 6 noted above.

\section{Robustness checks}

In this section, we investigate to what extent the results are robust with respect to several assumptions underlying our empirical model.

\subsection{Car owner and car user}

As we noted above, our data do not inform us about main user of the car, and until now we have proceeded on the basis of the assumption that the owner is also the main user. However, this assumption is not necessarily true; for example, in more than $50 \%$ of the households in our sample both cars have the same owner. The background of this phenomenon is that ownership as registered in our data is not necessarily related to use. It may happen that one person in the household (say, the one involved most in financial decisions) will be the owner of the car, while the two partners are the main driver of one of these cars. Alternatively, it may be the case that one person in the household is both the registered owner and the main user of both cars. For instance, this owner may use one of the cars for work trips and the other for leisure trips, while the second adult in the household does not use any of the cars because, for example, (s)he does not have a driver's license.

To investigate the possible significance of this issue, we have estimated the model separately for households (i) in which one person owns both cars, and households (ii) in which the two cars are owned by different persons (which are then presumably also the main drivers). The results are reported in Table 8 . In both cases we find negative own price effects and positive 
substitution effects of the same order of magnitude as in Table 3 above. Although the values of the estimated coefficients are different, a standard F-test shows that the coefficients are not statistically different at any usually applied confidence criteria. ${ }^{20}$

Table 8. First-difference demand models (SUR) when the cars are owned by the same person

\begin{tabular}{|c|c|c|c|c|}
\hline & \multicolumn{2}{|c|}{ Both cars owned by the same person } & \multicolumn{2}{|c|}{ Cars owned by different persons } \\
\hline & car 1 & car 2 & car 1 & $\operatorname{car} 2$ \\
\hline Change in fuel cost per kilometre, car 1 (DKK/km) & $\begin{array}{l}-1.504 * * * \\
(0.322)\end{array}$ & $\begin{array}{l}1.989 * * * \\
(0.435)\end{array}$ & $\begin{array}{l}-1.785 * * * \\
(0.346)\end{array}$ & $\begin{array}{l}1.125^{* *} \\
(0.441)\end{array}$ \\
\hline \multirow[t]{2}{*}{ Change in fuel cost per kilometre, car 2 (DKK/km) } & $1.461 * *$ & $-2.969 * * *$ & 0.791 & $-1.833^{* *}$ \\
\hline & $(0.609)$ & $(0.821)$ & $(0.653)$ & $(0.832)$ \\
\hline \multirow{2}{*}{ Change in log of household's income (1000 DKK) } & $0.032 * *$ & 0.018 & 0.022 & 0.011 \\
\hline & $(0.014)$ & $(0.020)$ & $(0.015)$ & $(0.020)$ \\
\hline \multirow{2}{*}{ Change in number of persons in household } & $-0.019 * *$ & -0.016 & -0.009 & -0.007 \\
\hline & $(0.008)$ & $(0.011)$ & $(0.009)$ & $(0.011)$ \\
\hline \multirow[t]{2}{*}{ Change in number of adults in household } & $0.018 *$ & $0.048 * * *$ & 0.015 & 0.011 \\
\hline & $(0.010)$ & $(0.013)$ & $(0.010)$ & $(0.013)$ \\
\hline \multirow[t]{2}{*}{ Change of presence of children in household } & 0.014 & $0.030^{* *}$ & 0.014 & 0.024 \\
\hline & $(0.011)$ & $(0.015)$ & $(0.012)$ & $(0.016)$ \\
\hline \multirow[t]{2}{*}{ Change in commuting distance $(\mathrm{km})$} & $0.0002^{* *}$ & $0.0003^{*}$ & $0.001^{* * *}$ & $0.001 * * *$ \\
\hline & $(0.0001)$ & $(0.0002)$ & $(0.0001)$ & $(0.0002)$ \\
\hline \multirow[t]{2}{*}{ Change in labour supply (1000 hours /year) } & $1.53 e-08$ & $5.15 e-06$ & $-4.21 e-06$ & $-4.36 e-06$ \\
\hline & $(4.12 \mathrm{e}-06)$ & $(5.56 \mathrm{e}-06)$ & $(3.99 \mathrm{e}-06)$ & $(5.08 \mathrm{e}-06)$ \\
\hline R-squared & 0.003 & 0.004 & 0.006 & 0.003 \\
\hline No. of observations & 12,257 & 12,257 & 10,544 & 10,544 \\
\hline
\end{tabular}

Notes: dependent variable is chg. in $\log (\mathrm{km} / \mathrm{month}) ;{ }^{* * *}, * *, *$ indicate that estimates are significantly different from zero at the 0.01 , at the 0.05 and the 0.10 level, respectively; robust standard errors are in parentheses.

Since we have found that the extended model developed and estimated in section 5 differed significantly from the one used in Section 4, it is interesting to go one step further and also estimate this model on the two subsamples. If two cars are owned and used by the same person, the common sense idea that substitution in response to a price will especially refer to a switch in car use from the least to the most fuel efficient car might seem even more likely than in the case in which two persons are involved. Although we cannot be sure that in all cases in which one person is the registered owner there is also only one predominant user of the two cars, we have estimated the alternative model separately for the two groups. The results are presented in Table 9.

\footnotetext{
${ }^{20}$ Standard F-tests reject the hypotheses that the own price effects and the substitution effects for households in which one person owns both cars and household in which the two cars are owned by different persons are different, i.e. for the own price effect car $1(\mathrm{~F}=0.22$; $\mathrm{p}$-value $=0.51)$, for the cross price effect car $1(\mathrm{~F}=0.26$; $\mathrm{p}$-value $=0.47)$, for the own price effect car $2(\mathrm{~F}=0.74 ; \mathrm{p}$-value $=0.19)$, and for the cross price effect car $2(\mathrm{~F}=0.46 ; \mathrm{p}$-value $=0.34)$.
} 
These results are qualitatively similar to each other, and to the results discussed above for the whole sample. Substitution from car 2 to car 1 is stronger when car 1 is the most fuel efficient one, as predicted by the alternative model. However, substitution from car 1 to car 2 is more important when car 1 is the most fuel efficient one, which contradicts that model. We conclude therefore that the results of our analysis do not change qualitatively when we distinguish between households with one and two owners of the cars.

Table 9. First-difference demand (SUR) models with interactions terms when the cars are owned by the same person

\begin{tabular}{|c|c|c|c|c|}
\hline & \multicolumn{2}{|c|}{$\begin{array}{l}\text { Both cars owned by the same } \\
\text { person }\end{array}$} & \multicolumn{2}{|c|}{ Cars owned by different persons } \\
\hline & car 1 & $\operatorname{car} 2$ & car 1 & $\operatorname{car} 2$ \\
\hline Change in fuel cost per kilometre, car 1 (DKK/ km) & $\begin{array}{l}-3.602 * * * \\
(0.578)\end{array}$ & $\begin{array}{l}3.755 * * * \\
(0.782)\end{array}$ & $\begin{array}{l}-3.013 * * * \\
(0.673)\end{array}$ & $\begin{array}{l}2.218 * * \\
(0.859)\end{array}$ \\
\hline Change in fuel cost per kilometre, car 2 (DKK/ km) & $\begin{array}{l}3.076 * * * \\
(0.901)\end{array}$ & $\begin{array}{l}-4.897 * * * \\
(1.219)\end{array}$ & $\begin{array}{l}2.518 * * \\
(0.990)\end{array}$ & $\begin{array}{l}-2.817 * * \\
(1.263)\end{array}$ \\
\hline $\begin{array}{l}\text { Change in fuel cost per kilometre, car } 1 \text { (DKK/ km) * dummy } \\
\text { variable indicating that car } 2 \text { is more fuel efficient }\end{array}$ & $\begin{array}{l}2.947 * * * \\
(0.695)\end{array}$ & $\begin{array}{l}-2.545 * * * \\
(0.941)\end{array}$ & $\begin{array}{l}1.620 * * \\
(0.785)\end{array}$ & $\begin{array}{l}-1.477 \\
(1.001)\end{array}$ \\
\hline $\begin{array}{l}\text { Change in fuel cost per kilometre, car } 2 \text { (DKK/ km) * dummy } \\
\text { variable indicating that car } 2 \text { is more fuel efficient }\end{array}$ & $\begin{array}{l}-0.998 \\
(1.244)\end{array}$ & $\begin{array}{l}2.923^{*} \\
(1.684)\end{array}$ & $\begin{array}{l}-2.198 \\
(1.343)\end{array}$ & $\begin{array}{l}1.311 \\
(1.714)\end{array}$ \\
\hline Change in log of household's income (1000 DKK) & $\begin{array}{l}0.033 * * \\
(0.014)\end{array}$ & $\begin{array}{l}0.018 \\
(0.020)\end{array}$ & $\begin{array}{l}0.023 \\
(0.015)\end{array}$ & $\begin{array}{l}0.011 \\
(0.020)\end{array}$ \\
\hline Dummy variable indicating that car 2 is more fuel efficient & $\begin{array}{l}0.071 * * * \\
(0.012)\end{array}$ & $\begin{array}{l}-0.026 \\
(0.017)\end{array}$ & $\begin{array}{l}0.067 * * * \\
(0.013)\end{array}$ & $\begin{array}{l}-0.014 \\
(0.017)\end{array}$ \\
\hline Change in number of persons in household & $\begin{array}{l}-0.019 * * \\
(0.008)\end{array}$ & $\begin{array}{l}-0.016 \\
(0.011)\end{array}$ & $\begin{array}{l}-0.009 \\
(0.009)\end{array}$ & $\begin{array}{l}-0.007 \\
(0.011)\end{array}$ \\
\hline Change in number of adults in household & $\begin{array}{l}0.017^{*} \\
(0.010)\end{array}$ & $\begin{array}{l}0.049 * * * \\
(0.013)\end{array}$ & $\begin{array}{l}0.014 \\
(0.010)\end{array}$ & $\begin{array}{l}0.011 \\
(0.013)\end{array}$ \\
\hline Change of presence of children in household & $\begin{array}{l}0.012 \\
(0.011)\end{array}$ & $\begin{array}{l}0.030 * * \\
(0.015)\end{array}$ & $\begin{array}{l}0.013 \\
(0.012)\end{array}$ & $\begin{array}{l}0.024 \\
(0.016)\end{array}$ \\
\hline Change in commuting distance $(\mathrm{km})$ & $\begin{array}{l}0.0002^{*} \\
(0.0001)\end{array}$ & $\begin{array}{l}0.0003^{*} \\
(0.0002)\end{array}$ & $\begin{array}{l}0.001 * * * \\
(0.0001)\end{array}$ & $\begin{array}{l}0.001 * * * \\
(0.0002)\end{array}$ \\
\hline Change in labour supply (1000 hours / year) & $\begin{array}{l}-2.12 \mathrm{e}-07 \\
(4.10 \mathrm{e}-06)\end{array}$ & $\begin{array}{l}5.25 \mathrm{e}-06 \\
(5.55 \mathrm{e}-06)\end{array}$ & $\begin{array}{l}-3.88 \mathrm{e}-06 \\
(3.98 \mathrm{e}-06)\end{array}$ & $\begin{array}{l}-4.48 \mathrm{e}-06 \\
(5.08 \mathrm{e}-06)\end{array}$ \\
\hline R-squared & 0.010 & 0.005 & 0.010 & 0.003 \\
\hline No. of observations & 12,257 & 12,257 & 10,544 & 10,544 \\
\hline
\end{tabular}

\subsection{The impact of income}

As another sensitivity check, we considered the impact of household income on the own and cross price terms. The results are reported in Table 10. Although the theory does not offer predictions with respect to the impact of income on substitution, it seems reasonable to expect that substitution effects become smaller when income is higher. For example, when the main users of the two cars 
are different persons, substitution may involve using the other person's cars for some trips, which will require more coordination of the activities of both persons. When household income is higher, it may be easier to accept the higher driver cost so as to avoid these coordination issues. The results, listed in Table 10, partly confirm these expectations. The estimated coefficient for the cross effects of income and the price of car 2 in the demand equation for car 1 is negative, as expected. However, the coefficient of the cross effect of income and the price of car 1 in the demand equation of car 2 is positive. This contradicts our expectation, although it should be noted that this coefficient is only weakly significant (the p-value is 0.09 ).

Table 10. First-difference demand models with interactions with household's income

\begin{tabular}{|c|c|c|}
\hline & \multicolumn{2}{|c|}{ SUR } \\
\hline & car 1 & car 2 \\
\hline Change in fuel cost per kilometre, car 1 (DKK/ km) & $\begin{array}{l}-2.310 * * * \\
(0.884)\end{array}$ & $\begin{array}{l}-0.309 \\
(1.163)\end{array}$ \\
\hline Change in fuel cost per kilometre, car $2(\mathrm{DKK} / \mathrm{km})$ & $\begin{array}{l}3.649 * * * \\
(1.318)\end{array}$ & $\begin{array}{l}0.189 \\
(1.733)\end{array}$ \\
\hline $\begin{array}{l}\text { Change in fuel cost per kilometre, car } 1 \text { (DKK/ km) * log of } \\
\text { household's income (1000 DKK) }\end{array}$ & $\begin{array}{l}0.050 \\
(0.062)\end{array}$ & $\begin{array}{l}0.139 * \\
(0.082)\end{array}$ \\
\hline $\begin{array}{l}\text { Change in fuel cost per kilometre, car } 2(\mathrm{DKK} / \mathrm{km}) * \text { log of } \\
\text { household's income (1000 DKK) }\end{array}$ & $\begin{array}{l}-0.182 * * \\
(0.091)\end{array}$ & $\begin{array}{l}-0.189 \\
(0.119)\end{array}$ \\
\hline Change in log of household's income ( 1000 DKK) & $\begin{array}{l}0.106 \\
(0.065)\end{array}$ & $\begin{array}{l}0.039 \\
(0.086)\end{array}$ \\
\hline Change in number of persons in household & $\begin{array}{l}-0.014^{* *} \\
(0.006)\end{array}$ & $\begin{array}{l}-0.014^{*} \\
(0.008)\end{array}$ \\
\hline Change in number of adults in household & $\begin{array}{l}0.017^{* *} \\
(0.007)\end{array}$ & $\begin{array}{l}0.0316^{* * *} \\
(0.009)\end{array}$ \\
\hline Change of presence of children in household & $\begin{array}{l}0.014^{*} \\
(0.008)\end{array}$ & $\begin{array}{l}0.028 * * * \\
(0.011)\end{array}$ \\
\hline Change in commuting distance $(\mathrm{km})$ & $\begin{array}{l}0.0004^{* * *} \\
(0.0001)\end{array}$ & $\begin{array}{l}0.0005^{* * *} \\
(0.0001)\end{array}$ \\
\hline Change in labour supply (1000 hours / year) & $\begin{array}{l}-2.16 \mathrm{e}-06 \\
(2.86 \mathrm{e}-06) \\
\end{array}$ & $\begin{array}{l}1.94 \mathrm{e}-07 \\
(3.77 \mathrm{e}-06) \\
\end{array}$ \\
\hline $\begin{array}{l}\text { R-squared } \\
\text { No. of observations }\end{array}$ & $\begin{array}{l}0.004 \\
22,801\end{array}$ & $\begin{array}{l}0.003 \\
22,801\end{array}$ \\
\hline
\end{tabular}

\section{Conclusions}

The purpose of this paper was to study how two-car households react to changes in fuel prices that affect the relative per-kilometer cost of using the different cars. Based on a simple theoretical framework, we developed an econometric model to investigate whether and to what extent there is substitution between cars within the household. Using detailed Danish register data we estimated, 
for each car owned by the household, own and cross-price effects of increases in fuel prices. The empirical results point at important substitution effects, so that models that estimate responses to fuel prices on the implicit or explicit assumption of one car per household imply substantial biases.

Analyses of the substitution between cars within the household and estimates of the own and cross-price effects of increases in fuel prices (or more general, variable costs associated with the car use) are highly relevant for policy. For example, measurement of the substitution effects between cars in multiple car households can be a useful input in the on-going debate about the significance of rebound effects (see Linn (2013)). It is also highly relevant for the discussion as to whether or not to shift the tax burden from fixed taxes on ownership to variable costs of car use; see, for example, De Borger and Mayeres (2007) and Fosgerau and Jensen (2013). The analyses however ignore the multivehicle households in the population and their fleet composition. It is clear that the empirical models such as the one developed in this paper may be directly relevant for an evaluation of the implications of such policies because they allow one to evaluate the effect of higher variable costs on car usage and fuel consumption, taking account of the substitution effects between cars in multiple car households. Moreover, the implications of fuel efficiency standards can be evaluated. Finally, the share of two-car households is increasing. For example, the number of the two-car households in Denmark increased from 305,072 in 2007 to 370,435 in 2012 , or by $21 \%$. In the same period the share of the two-car household in the car-owner population increased from $18.8 \%$ to $21.7 \%$. So, the substitution between cars within the household in an analysis of car use in households should not be ignored. 


\section{References}

Allcott, H. and N. Wozny. 2010. Gasoline prices, fuel economy, and the energy paradox. CEEPR, 10-003, available at ftp://wuecon195.wustl.edu/opt/ReDIF/RePEc/mee/wpaper/2010-003.pdf .

Bento, A. M., L. H. Goulder, M. R. Jacobsen and R. H. von Haefen. 2009. Distributional and Efficiency Impacts of Increased US Gasoline Taxes. American Economic Review, 99(3), 1-37.

Bhat, C.R. and S. Sen. 2006. Household vehicle type holdings and usage: An application of the multiple discrete-continuous extreme value (MDCEV) model. Transportation Research B, 40, 35-53.

Busse, M.R., C.R. Knittel and F. Zettelmeyer. 2009. Pain at the pump: How gasoline prices affect automobile purchasing in new and used markets. Northwestern University, University of California, Davis, and National Bureau of Economic Research, mimeo, February, available at www.econ.ucdavis.edu/faculty/knittel/papers/gaspaper_latest.pdf.

Chia, N., A. Tsui and J. Whalley. 2001. Ownership and use taxes as congestion correcting instruments. NBER paper 8278.

De Borger, B. and I. Mayeres. 2007. Optimal taxation of car ownership, car use and public transport: insights derived from a discrete choice numerical optimization model. European Economic Review, 51, 11771204.

De Jong, G.C. 1990. An indirect utility model of car ownership and private car use. European Economic Review, 34, 971-985.

De Jong, G.C. 1991. A micro-economic model of the joint decision on car ownership and car use. In: Methods for Understanding Travel Behavior in the 1990s, Proceeding of the Conference International sur les Comportements de Deplacement, Quebec, pp. 387-403.

Deaton, A. and J. Muellbauer. 1980. Economics and consumer behaviour. Cambridge University Press, USA.

Dubin, J. and D. McFadden. 1984. An econometric analysis of residential electric appliance holding and consumption. Econometrica, 52, 345-362.

Feng, Y., D. Fullerton and L. Gan. 2005. Vehicle choices, miles driven and pollution policies. NBER paper 11553.

Fosgerau, M. and T. C. Jensen. 2013. A green reform is not always green. Transportation Research C, 30, 210-220.

Fullerton, D. and L. Gan. 2005. Cost-effective policies to reduce vehicle emissions, American Economic Review, 95, 300-304.

Gillingham, K. 2012. Selection on Anticipated Driving and the Consumer Response to Changing Gasoline Prices. Workin Paper, Yale University, School of Forestry \& Environmental Studies.

Golob, T.F., S. Kim and W. Ren. 1996. How households use different types of vehicles: a structural driver allocation and usage model. Transportation Research A, 30, 103-118. 
Golob, T.F. and M.G. McNally. 1997. A Model of Acticity Participation and Travel Interaction Between Household Heads. Tranportation Research B, 31, 177-194.

Hausman, J.A. and W. K. Newey. 1995. Nonparametric Estimation of Exact Consumers Surplus and Deadweight Loss. Econometrica, 63, 1445-76.

Heckman J., 1978. Dummy endogenous variables in a simultaneous equation system. Econometrica, 46, 931959.

Jacobsen, M. 2013. Evaluating U.S. Fuel Economy Standards in a Model with Producer and Household Heterogeneity. American Economic Journal: Economic Policy, forthcoming.

Klier, T. and J. Linn. 2010. The price of gasoline and new vehicle fuel economy: Evidence from monthly sales data. American Economic Journal: Economic Policy, 2, 134-153.

Li, S., C. Timmins and R. von Haefen. 2009. Do gasoline prices affect fleet fuel economy? American Economic Journal: Economic Policy, 1, 113-137.

Linn, J. 2013. The rebound effect for passenger vehicles. Resources for the Future, Discussion Paper.

Mannering, F. 1983. An econometric analysis of vehicle use in multivehicle households. Transportation Research A, 17, 183-189.

Mannering, F. and C. Winston. 1985. A dynamic empirical analysis of household vehicle ownership and utilization. Rand Journal of Economics, 16, 215-236.

Ruud, P.A. 2000. An Introduction to Classical Econometric Theory. Oxford University Press, New York, Oxford.

Train, K. 1986. Qualitative Choice Analysis: Theory, Econometrics and an Application to Automobile Demand. MIT Press, Boston, MA.

West, S. E. 2004. Distributional effects of alternative vehicle pollution control policies. Journal of Public Economics, 88, 735-757.

West, S. E. and R. C. Williams. 2005. The Cost of Reducing Gasoline Consumption. American Economic Review, 95(2), 294-299.

Wooldridge, J.M. 2010. Econometric Analysis of Cross Section and Panel Data. 2nd ed. MIT Press.

Zellner, A. 1962. An efficient method of estimating seemingly unrelated regressions and test of aggregation bias. Journal of American Statistical Association, 57, 500-509. 


\section{Appendix A.}

Figure A1. Histogram and kernel distribution for the difference of the fuel efficiency of the primary and the secondary car in a household

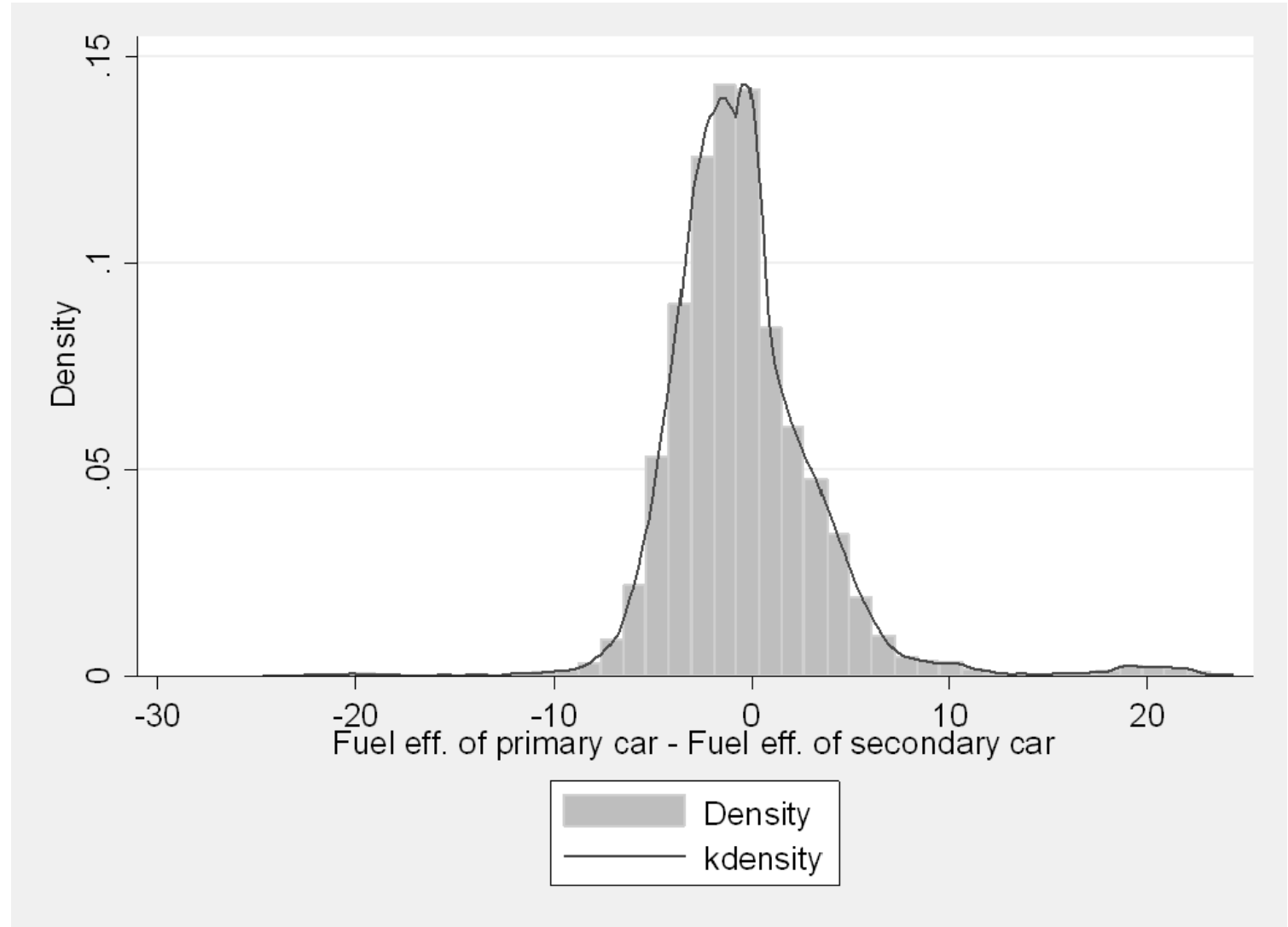

Notes: Number of observations: 22,801 . The secondary car in a household is more fuel efficient (consumes less fuel per kilometre) in $61.10 \%$ cases. 


\section{Appendix B}

Table B1. Summary statistics for two-cars-households that changed their car-stock

\begin{tabular}{|c|c|c|c|c|}
\hline Variable & Mean & Std. Dev. & Minimum & Maximum \\
\hline Number of driven kilometres, car 1 (1000 km/month) & 1.8168 & 0.7815 & 0.0909 & 7.8400 \\
\hline Fuel price, car 1 (DKK/I) & 8.3888 & 0.3849 & 6.8317 & 9.3770 \\
\hline Fuel efficiency, car $1(\mathrm{~km} / \mathrm{l})$ & 14.2179 & 3.3771 & 5.6000 & 33.3000 \\
\hline Car total weight, car $1(\mathrm{~kg})$ & $1,701.7420$ & 252.26910 & 975.0000 & $11,675.0000$ \\
\hline Engine horsepower, car 1 & 116.4674 & 33.9470 & 41.0000 & 463.7273 \\
\hline Car age, car 1 (years) & 6.0140 & 3.6036 & 0.0000 & 31.0000 \\
\hline Diesel engine (share), car 1 & 0.2002 & 0.4001 & 0.0000 & 1.0000 \\
\hline Car 1 owners age & 45.1697 & 11.4342 & 17.0000 & 84.0000 \\
\hline Male (share), car 1 & 0.7466 & 0.4350 & 0.0000 & 1.0000 \\
\hline Vocational education, owner of car 1 & 0.3994 & 0.4898 & 0.0000 & 1.0000 \\
\hline Short-cycle higher education, owner of car 1 & 0.0694 & 0.2542 & 0.0000 & 1.0000 \\
\hline Medium-cycle education, owner of car 1 & 0.1729 & 0.3781 & 0.0000 & 1.0000 \\
\hline Bachelor, owner of car 1 & 0.0116 & 0.1071 & 0.0000 & 1.0000 \\
\hline Long-cycle higher education, owner of car 1 & 0.1204 & 0.3255 & 0.0000 & 1.0000 \\
\hline PhD degree, owner of car 1 & 0.0058 & 0.0761 & 0.0000 & 1.0000 \\
\hline Alien (share), owner of car 1 & 0.0161 & 0.1260 & 0.0000 & 1.0000 \\
\hline Car 1 owners commuting distance $(\mathrm{km})$ & 21.0004 & 32.2328 & 0.0000 & 346.2220 \\
\hline Number of driven kilometres, car $2(1000 \mathrm{~km} /$ month $)$ & 0.9666 & 0.4598 & 0.0141 & 4.7778 \\
\hline Fuel price, car 2 (DKK/I) & 8.4383 & 0.2590 & 7.0071 & 9.2130 \\
\hline Fuel efficiency, car 2 (km/l) & 14.5208 & 2.4915 & 6.0000 & 33.3000 \\
\hline Car total weight, car $2(\mathrm{~kg})$ & $1,509.9850$ & 226.7868 & 900.0000 & $3,400.0000$ \\
\hline Engine horsepower, car 2 & 98.0025 & 30.3853 & 26.0000 & 388.2857 \\
\hline Car age, car 2 (years) & 8.4116 & 4.8920 & 0.0000 & 44.0000 \\
\hline Diesel engine (share), car 2 & 0.0557 & 0.2294 & 0.0000 & 1.0000 \\
\hline Car 2 owners age & 44.8258 & 11.5269 & 17.0000 & 84.0000 \\
\hline Male, car 2 (share) & 0.6290 & 0.4831 & 0.0000 & 1.0000 \\
\hline Vocational education, owner of car 2 & 0.3975 & 0.4894 & 0.0000 & 1.0000 \\
\hline Short-cycle higher education, owner of car 2 & 0.0678 & 0.2513 & 0.0000 & 1.0000 \\
\hline Medium-cycle education, owner of car 2 & 0.1800 & 0.3842 & 0.0000 & 1.0000 \\
\hline Bachelor, owner of car 2 & 0.0123 & 0.1104 & 0.0000 & 1.0000 \\
\hline Long-cycle higher education, owner of car 2 & 0.1072 & 0.3094 & 0.0000 & 1.0000 \\
\hline PhD degree, owner of car 2 & 0.0058 & 0.0761 & 0.0000 & 1.0000 \\
\hline Alien (share), owner of car 2 & 0.0161 & 0.1260 & 0.0000 & 1.0000 \\
\hline Car 2 owners commuting distance $(\mathrm{km})$ & 19.0631 & 30.2611 & 0.0000 & 431.0290 \\
\hline Household's income (1000 DKK) & 808.9630 & 328.5031 & 201.4880 & $2,998.2450$ \\
\hline Number of persons in household & 3.1348 & 1.0666 & 1.0000 & 9.0000 \\
\hline Baby (share) & 0.0581 & 0.2339 & 0.0000 & 1.0000 \\
\hline Children 1-6 years old (share) & 0.2414 & 0.4279 & 0.0000 & 1.0000 \\
\hline Children $7-18$ years old (share) & 0.3981 & 0.4895 & 0.0000 & 1.0000 \\
\hline Change in number of driven kilometres, car 1 (1000 km/month) & -0.2734 & 0.8322 & -4.4904 & 4.4483 \\
\hline Change in number of driven kilometres, car $2(1000 \mathrm{~km} / \mathrm{month})$ & 0.0958 & 0.6480 & -3.2349 & 4.4844 \\
\hline Change in fuel cost per kilometre, $\operatorname{car} 1$ (DKK/km) & 0.0017 & 0.0143 & -0.0739 & 0.0644 \\
\hline Change in fuel cost per kilometre, car $2(\mathrm{DKK} / \mathrm{km})$ & 0.0069 & 0.0081 & -0.0496 & 0.0650 \\
\hline Change in household's income (1000 DKK) & 244.9211 & $1,590.9340$ & $-2,522.2980$ & $2,550,000.0000$ \\
\hline
\end{tabular}




\section{Appendix C}

Table C1. First stage of the Heckman selection model (Table 3)

\begin{tabular}{|c|c|c|}
\hline & \multicolumn{2}{|c|}{ [4] } \\
\hline \multirow[t]{2}{*}{ Age of the oldest car in household (inst.) } & $0.008^{* * *}$ & $0.008^{* * *}$ \\
\hline & $(0.001)$ & $(0.001)$ \\
\hline \multirow[t]{2}{*}{ Change in log of household's income (1000 DKK) } & $-0.150 * * *$ & $-0.151 * * *$ \\
\hline & $(0.023)$ & (0.021) \\
\hline \multirow[t]{2}{*}{ Change in number of persons in household } & $-0.057^{* * *}$ & $-0.057 * * *$ \\
\hline & $(0.013)$ & $(0.013)$ \\
\hline \multirow[t]{2}{*}{ Change in number of adults in household } & $0.032^{* *}$ & $0.032 * * *$ \\
\hline & $(0.013)$ & $(0.012)$ \\
\hline \multirow[t]{2}{*}{ Change of presence of children in household } & -0.001 & -0.001 \\
\hline & $(0.014)$ & (0.019) \\
\hline \multirow[t]{2}{*}{ Change in commuting distance $(\mathrm{km})$} & $-0.001 * * *$ & $-0.001 * * *$ \\
\hline & $(0.0002)$ & $(0.0002)$ \\
\hline \multirow[t]{2}{*}{ Change in labour supply (1000 hours /year) } & $-7.71 \mathrm{e}-06$ & $-7.63 e-06$ \\
\hline & $(5.37 e-06)$ & $(4.91 e-06)$ \\
\hline Rho & 0.405 & -0.905 \\
\hline Sigma & 0.480 & 0.829 \\
\hline No. of observations & 39,031 & 39,037 \\
\hline
\end{tabular}


Appendix D. The figures below show the change in the logarithm of the number of kilometres on the vertical axis and the change in the variable cost of the car on the horizontal axis. Figure D1 refers to cars 1 only, the figure D2 to cars 2 only. In both figures a line is drawn that refers to simple regression of the two variables. In both figures the line has a negative slope, as would be expected. No control variables have been included. Figure D3 refers to all observations, both cars 1 and cars 2, and now the simple regression does no longer have a negative slope. The reason is that many of the observations referring to cars 2 lie above and to the right of those referring to cars 1 , as is shown in the figure D4. It is mainly for this reason that the negative effect of the price disappears in the simple regression and becomes positive if controls are introduced, as reported in column [3] of Table 4. 
Figure D1. Change in fuel cost per kilometre $(P)$ and change in $\log (\mathrm{km} / \mathrm{month})$ for the primary car (when households are treated as one-car households)

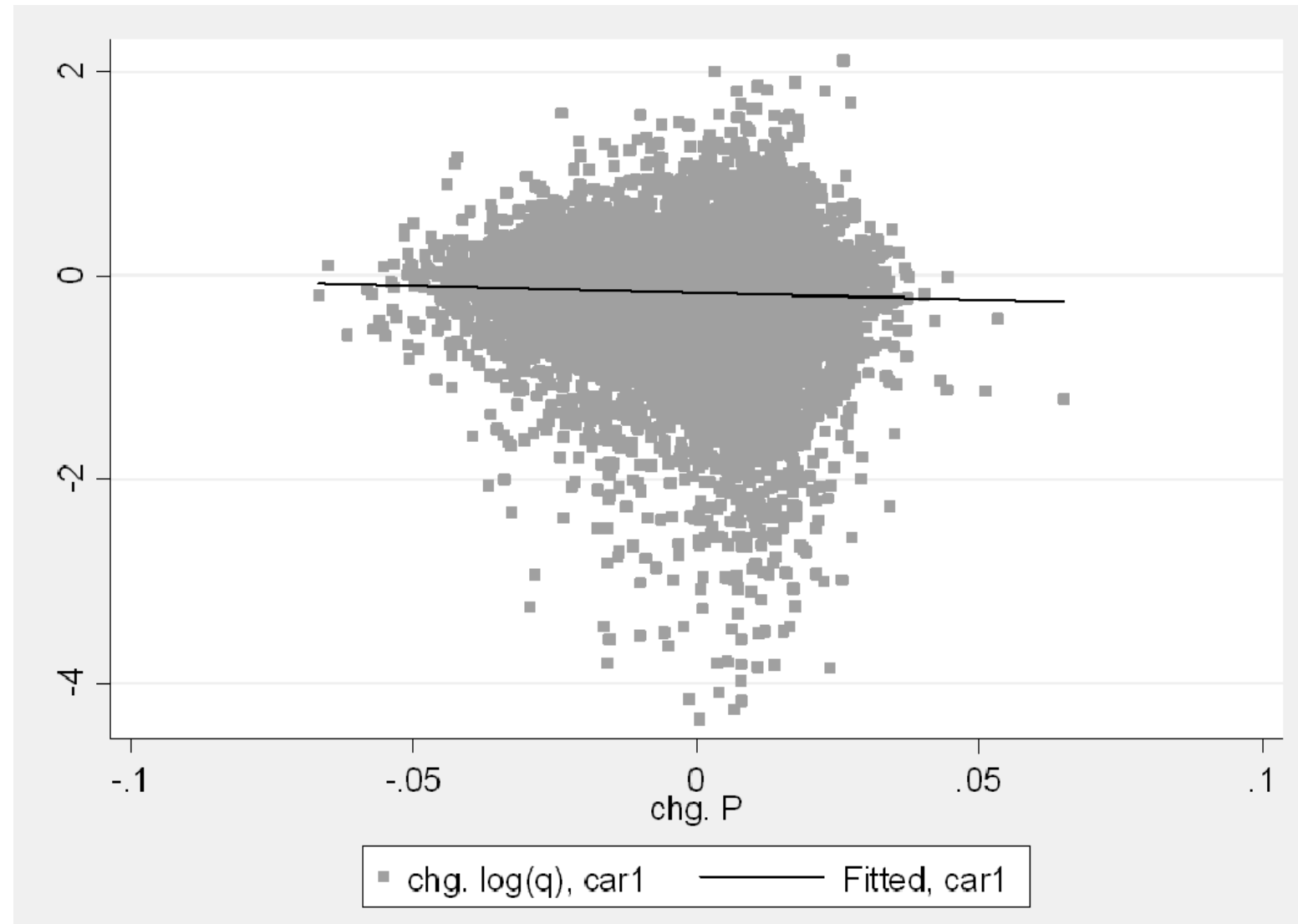

Notes: Number of observations: 22,801 
Figure D2. Change in fuel cost per kilometre $(P)$ and change in $\log (\mathrm{km} / \mathrm{month})$ for the secondary car (when households are treated as one-car households)

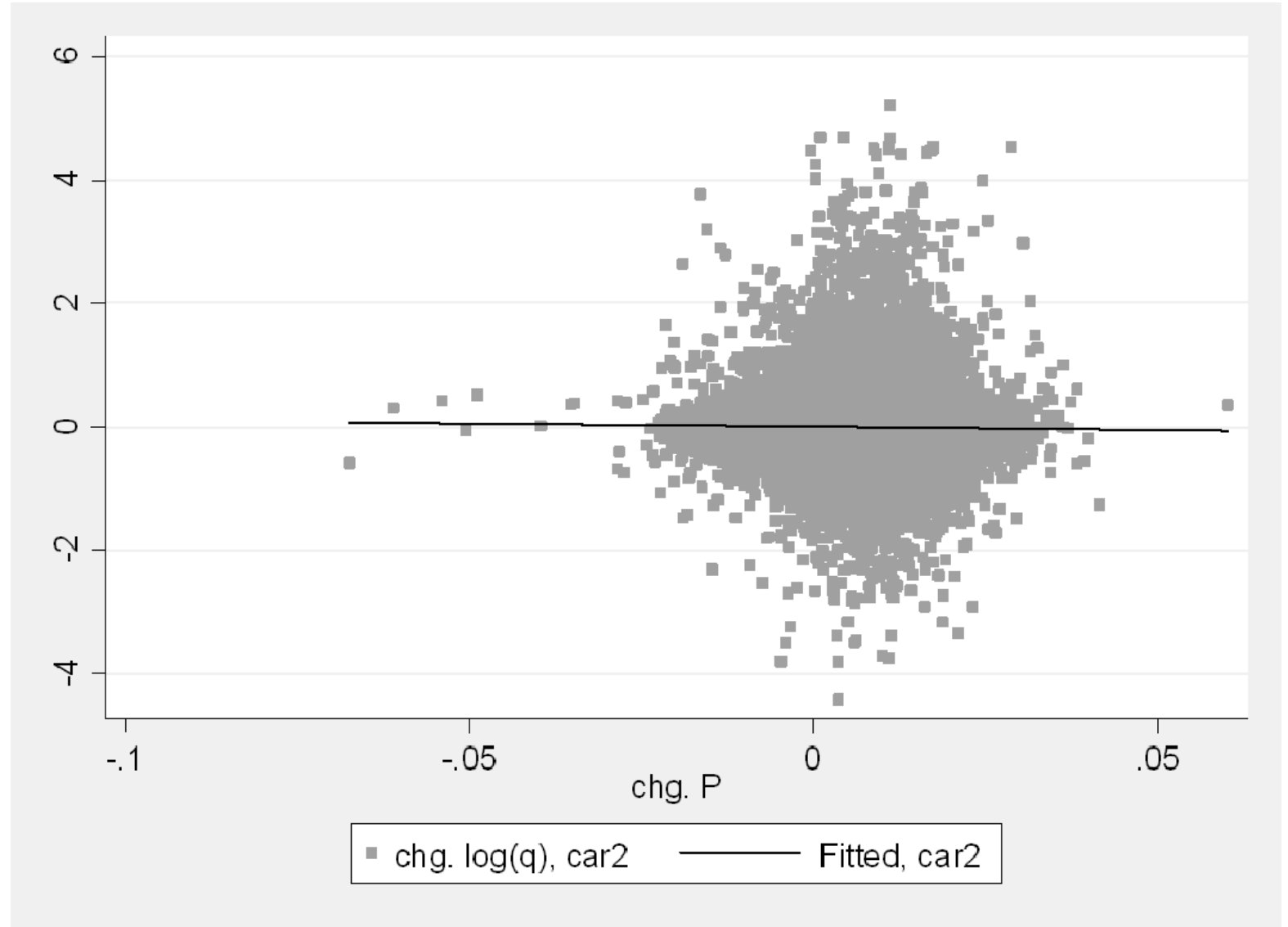

Notes: Number of observations: 22,801. 
Figure D3. Change in fuel cost per kilometre $(P)$ and change in $\log (\mathrm{km} / \mathrm{month})$ for both cars 1 and cars 2 (when households are treated as one-car households)

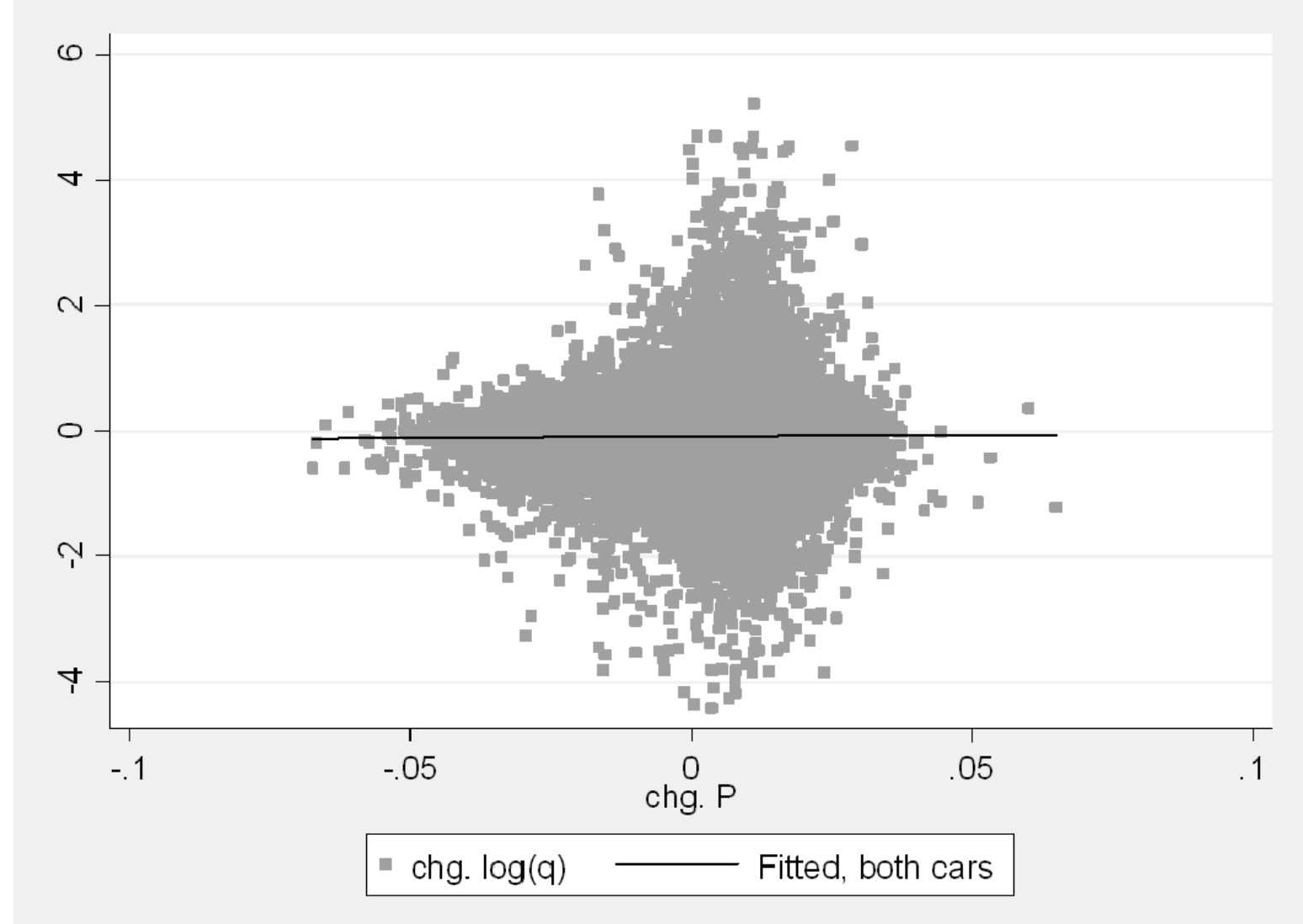

Notes: Number of observations: 22,801. 
Figure D4. Change in fuel cost per kilometre $(P)$ and change in $\log (\mathrm{km} / \mathrm{month})$ for the primary cars, the secondary cars, and both cars (when households are treated as one-car households)

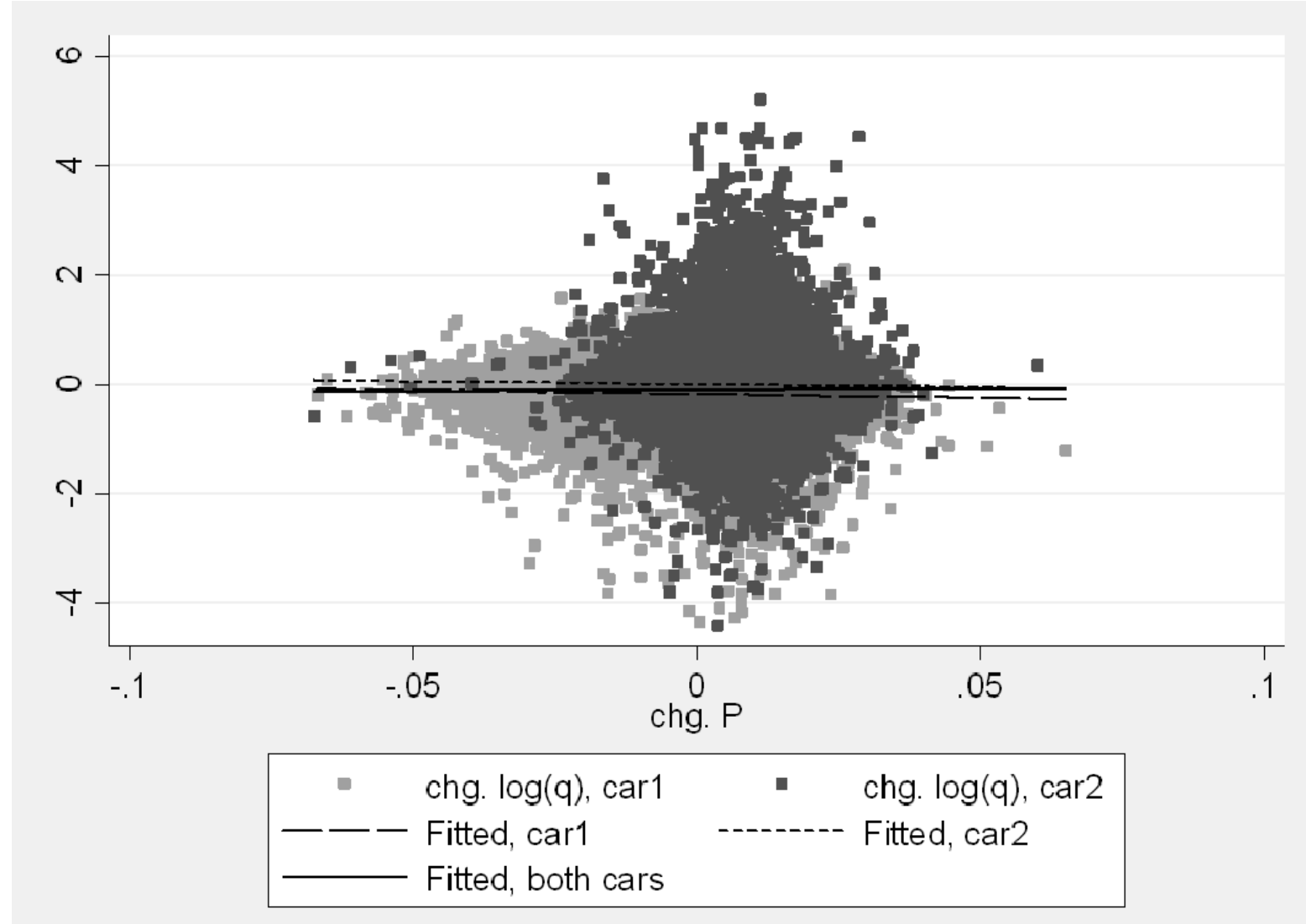

Notes: Number of observations: 22,801. 


\section{Appendix E.}

Table E1. Means and standard deviations for different samples

\begin{tabular}{|c|c|c|c|c|}
\hline \multirow[t]{2}{*}{ Variable } & \multicolumn{2}{|c|}{ Car 1 more fuel efficient } & \multicolumn{2}{|c|}{ Car 2 more fuel efficient } \\
\hline & Mean & Std. Dev. & Mean & Std. Dev. \\
\hline Number of driven kilometres, car 1 (1000 km/month) & 1.8578 & 0.9262 & 1.6800 & 0.7508 \\
\hline Fuel price, car 1 (DKK/I) & 8.2808 & 0.4274 & 8.4863 & 0.3026 \\
\hline Fuel efficiency, car 1 (km/l) & 16.3053 & 4.1535 & 12.5057 & 1.5606 \\
\hline Car total weight, car 1 (kg) & $1,589.7580$ & 244.0679 & $1,778.3670$ & 302.9573 \\
\hline Engine horsepower, car 1 & 99.2572 & 26.7225 & 128.9839 & 32.6770 \\
\hline Car age, car 1 (years) & 5.8856 & 3.9388 & 6.1151 & 3.3915 \\
\hline Diesel engine (share), car 1 & 0.3340 & 0.4717 & 0.0605 & 0.2384 \\
\hline Car 1 owners age & 48.7993 & 11.6123 & 50.0242 & 11.5212 \\
\hline Male (share), car 1 & 0.6848 & 0.4646 & 0.7872 & 0.4093 \\
\hline Vocational education, owner of car 1 & 0.3591 & 0.4798 & 0.3618 & 0.4805 \\
\hline Short-cycle higher education, owner of car 1 & 0.0754 & 0.2641 & 0.0599 & 0.2374 \\
\hline Medium-cycle education, owner of car 1 & 0.1938 & 0.3953 & 0.1950 & 0.3962 \\
\hline Bachelor, owner of car 1 & 0.0088 & 0.0934 & 0.0091 & 0.0950 \\
\hline Long-cycle higher education, owner of car 1 & 0.1331 & 0.3398 & 0.1655 & 0.3717 \\
\hline PhD degree, owner of car 1 & 0.0090 & 0.0945 & 0.0097 & 0.0980 \\
\hline Alien (share), owner of car 1 & 0.0176 & 0.1315 & 0.0177 & 0.1320 \\
\hline Car 1 owners commuting distance $(\mathrm{km})$ & 20.9589 & 29.6352 & 17.0972 & 28.1838 \\
\hline Number of driven kilometres, car $2(1000 \mathrm{~km} /$ month $)$ & 0.9841 & 0.4984 & 0.8466 & 0.4561 \\
\hline Fuel price, car 2 (DKK/l) & 8.4559 & 0.2500 & 8.4206 & 0.2341 \\
\hline Fuel efficiency, car 2 (km/l) & 13.2352 & 1.8926 & 15.1411 & 2.1365 \\
\hline Car total weight, car 2 (kg) & $1,632.1650$ & 276.7820 & $1,435.5020$ & 213.0958 \\
\hline Engine horsepower, car 2 & 112.3846 & 33.3396 & 89.1069 & 22.8764 \\
\hline Car age, car 2 (years) & 8.6694 & 4.8685 & 8.8747 & 5.3754 \\
\hline Diesel engine (share, car 2) & 0.0395 & 0.1947 & 0.0433 & 0.2035 \\
\hline Car 2 owners age & 49.1684 & 11.6193 & 49.3193 & 11.5627 \\
\hline Male, car 2 (share) & 0.6953 & 0.4603 & 0.5616 & 0.4962 \\
\hline Vocational education, owner of car 2 & 0.3703 & 0.4829 & 0.3687 & 0.4825 \\
\hline Short-cycle higher education, owner of car 2 & 0.0685 & 0.2527 & 0.0643 & 0.2453 \\
\hline Medium-cycle education, owner of car 2 & 0.1915 & 0.3935 & 0.1983 & 0.3988 \\
\hline Bachelor, owner of car 2 & 0.0074 & 0.0859 & 0.0111 & 0.1046 \\
\hline Long-cycle higher education, owner of car 2 & 0.1311 & 0.3375 & 0.1363 & 0.3431 \\
\hline PhD degree, owner of car 2 & 0.0079 & 0.0885 & 0.0093 & 0.0958 \\
\hline Alien (share), owner of car 2 & 0.0176 & 0.1315 & 0.0177 & 0.1320 \\
\hline Car 2 owners commuting distance $(\mathrm{km})$ & 18.1523 & 29.0305 & 14.9284 & 25.4028 \\
\hline Household's income (1000 DKK) & 745.4151 & 314.2636 & 782.2750 & 337.8761 \\
\hline Number of persons in household & 2.9149 & 1.0881 & 2.9019 & 1.0784 \\
\hline Baby (share) & 0.0424 & 0.2015 & 0.0440 & 0.2051 \\
\hline Children 1-6 years old (share) & 0.1808 & 0.3849 & 0.1841 & 0.3876 \\
\hline Children $7-18$ years old (share) & 0.3340 & 0.4717 & 0.3252 & 0.4685 \\
\hline Both cars owned by the same household member & 0.5636 & 0.4960 & 0.5210 & 0.4996 \\
\hline Share of households with both cars using same fuel type & 0.6874 & 0.4636 & 0.9248 & 0.2638 \\
\hline Change in number of driven kilometres, car 1 (1000 km/month) & -0.2986 & 0.7969 & -0.1980 & 0.6587 \\
\hline Change in number of driven kilometres, car $2(1000 \mathrm{~km} /$ month $)$ & 0.0497 & 0.5519 & 0.0496 & 0.5641 \\
\hline Change in fuel cost per kilometre, car 1 (DKK/km) & 00026 & 0.0131 & 0.0018 & 0.0148 \\
\hline Change in fuel cost per kilometre, car $2(\mathrm{DKK} / \mathrm{km})$ & 0.0087 & 0.0087 & 0.0071 & 0.0066 \\
\hline Change in household's income (1000 DKK) & 128.3616 & 429.4892 & 121.2718 & 368.9038 \\
\hline Number of observations & 8,870 & & 13,931 & \\
\hline
\end{tabular}


Figure E1. Effect of an increase in the fuel cost per kilometre by 10 cents on demand for kilometres ( $\mathrm{km} / \mathrm{month})$
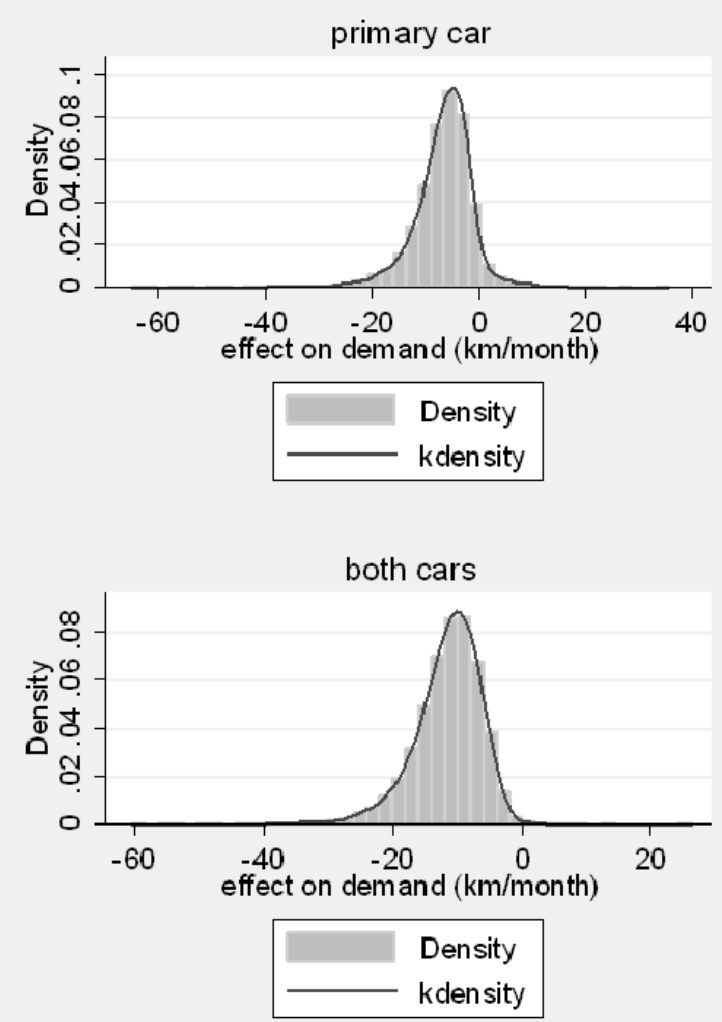

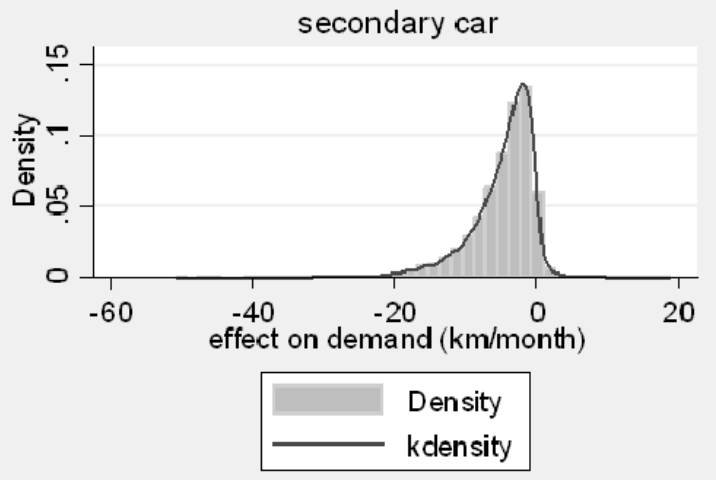

Notes: Number of observations: 22,801. An increase in the fuel cost per kilometre by 10 cents implies a decrease in demand for kilometres for the primary car in $93.98 \%$ of cases, for the secondary car in $95.71 \%$ of cases, and in total in $99.77 \%$ of cases. 